\title{
Toward an integrated system for fire, smoke, and air quality simulations
}

\author{
Adam K. Kochanski ${ }^{1}$, Mary Ann Jenkins², Kara Yedinak ${ }^{3}$, Jan Mandel ${ }^{4}$, Jonathan D. \\ Beezley $^{5}$, and Brian Lamb ${ }^{6}$ \\ ${ }^{1}$ Department of Atmospheric Sciences, University of Utah, 135 S 1460 E, RM819, 84112 \\ Salt Lake City, UT, USA, adam.kochanski@utah.edu \\ ${ }^{3}$ University of Idaho, College of Natural Resources, Forest, Rangeland, and Fire Sciences \\ Department, ID, USA \\ ${ }^{4}$ University of Colorado Denver, Denver, CO, USA \\ ${ }^{5}$ Kitware, Inc., 28 Corporate Drive, Clifton Park, New York 12065 \\ ${ }^{6}$ Laboratory for Atmospheric Research, Department of Civil \& Environmental Engineering, \\ Washington State University, WA, USA
}

October 7, 2018

\begin{abstract}
In this study, we describe how WRF-Sfire is coupled with WRF-Chem to construct WRFSC, an integrated forecast system for wildfire and smoke prediction. The integrated forecast system has the advantage of not requiring a simple plume-rise model and assumptions about the size and heat release from the fire in order to determine fire emissions into the atmosphere. With WRF-Sfire, wildfire spread, plume and plume-top heights are predicted directly, at every WRF time-step, providing comprehensive meteorology and fire emissions to the chemical transport model WRF-Chem.

Evaluation of WRFSC was based on comparisons between available observations to the results of two WRFSC simulations.

The study found overall good agreement between forecasted and observed fire spread and smoke transport for the Witch-Guejito fire. Also the simulated PM2.5 (fine particulate matter) peak concentrations matched the observations. However, the NO and ozone levels were underestimated in the simulations and the peak concentrations were mistimed. Determining the terminal or plume-top height is one of the most important aspects of simulating wildfire plume transport, and the study found overall good agreement between simulated and observed plume-top heights, with some ( $10 \%$ or less) underestimation by the simulations. One of the most promising results of the study was the agreement between passive-tracer modeled plumetop heights for the Barker Canyon fire simulation and observations. This simulation took only $13 \mathrm{~h}$, with the first $24 \mathrm{~h}$ forecast ready in almost $3 \mathrm{~h}$, making it a possible operational tool for providing emission profiles for external chemical transport models.
\end{abstract}




\section{Introduction}

The United States 2009 Federal Wildland Fire Policy and the Clean Air Act have significantly broadened regulatory and management requirements by making assessment of air quality and visibility impacts from wildland fires mandatory. Because fire emissions can contribute to a violation of the National Ambient Air Quality Standards, wildland fire managers in the United States must consider the impacts of smoke on regional air quality and visibility. The adverse effects of smoke, described by Hardy et al. (2001), are particular concerns when planning prescribed burns or evacuations of populations at risk of smoke exposure. An increase in PM (Particulate Matter) levels due to forest fires may result in an increase of upper-respiratory track illness, asthma, and rhinitis, serious health concerns associated with wildfire emissions (Emmanuel, 2000).

Forecast tools of varying complexity are available to assess smoke dispersion at the regional scale. They range from simple Gaussian models such as VSMOKE (Lavdas, 1996) and SASEM (Sestak and Riebau, 1988) that predict the area affected by smoke based on fuel type, fire area, and wind conditions, to models such as CALPUFF (Scire, 2000) for applications involving long-range transport, and finally to more complex multi-model systems like BlueSky (Larkin et al., 2009) that predict emissions, dispersion, and air quality effects associated with wildland fires.

Even though plume models of various complexity exist, their physical descriptions of transport and dispersion of smoke from a wildland fire are generally inadequate. A performance evaluation of several widely used operational plume-rise models can be found in Val Martin et al. (2012), while a critical review of various smoke transport models can be found in Goodrick et al. (2012). Typically, assumptions are made about the size and heat release of the fire, and the vertical distribution of pollutants is represented either by a prescribed plume-rise and smoke-injection height or by simple smoke stack plume-rise algorithms. Also, the lack of physical representation of the spatial and temporal variability of the fire heat release in these models limits them in terms of realistic rendering of plume rise and smoke emissions.

Clearly, the dispersion and transport of smoke from wildfires is a multi-disciplinary, multi-scale problem, affected directly by meteorology. Plume-rise is driven by the active fire area, total fire heat flux, and fuel moisture content of burning vegetation, all of which depend on local meteorology (Freitas et al., 2007, 2010). Atmospheric humidity and temperature affect fuel moisture, which in turn influences heat release and fire spread. The wind field, atmospheric stability, and evolution of the atmospheric boundary layer affect pyro-plume development and smoke injection heights. Weather also governs smoke dispersion and the chemical reactions that take place as the smoke plume is advected downwind from the fire.

Studies (Val Martin et al., 2012, and references therein) indicate that accurate plume-rise prediction requires input of time-dependent meteorological conditions (winds, humidity, atmospheric stability, evolution of the atmospheric boundary layer), accurate sensible heat values from the burning area of a propagating wildfire, as well as the representation of the buoyancy and pressure gradient forces associated with pyro-convection. In this work we attempt to address these problems with an integrated smoke prediction system formed by coupling WRF-Sfire (Mandel et al., 2011) with the chemical transport model WRF-Chem (Grell et al., 2005). Unlike current modelling frameworks that prescribe fire activity and simplify fire emissions to a single plume whose vertical extent is estimated by a simple plume rise model, the coupled WRF-Sfire-Chem aims to predict pyro-plume 
development, and smoke dispersion and its air quality impacts, without separate, external model components, by comprehensively resolving fire spread, heat release during flaming combustion, fire emissions, fire plume rise, as well as downwind smoke dispersion and associated chemistry.

Our concept is similar to that by Trentmann et al. (2006), who used the non-hydrostatic, highresolution ATHAM (Active Tracer High Resolution Atmospheric Model) to simulate a forest fire plume. The major difference between Trentmann et al.'s approach and the one investigated here is that the heat and emission fluxes associated with the fire are predicted, not prescribed based on available observations. Instead, the WRF-Sfire modelling system resolves explicitly fire progression and surface heat release depending on fuel and weather conditions forecasted by WRF. Coupling WRF-Sfire with WRF-Chem enhances the capabilities of each, providing numerical prediction of fire progression, plume rise, as well as short-range and long-range transport of pollution caused by wildfires.

The paper is organized as follows. Descriptions of the WRF-Sfire, WRF-Chem, and the coupled WRF-Sfire/WRF-Chem model, hereafter refereed to as WRFSC, are given in Section 2. The WRFSC simulation of the 2007 Witch-Guejito fire, examined in Section 3, is used to evaluate how well WRFSC represents: the local dispersion (Section 3.2) and the long-range dispersion (Section 3.3) of fire PM2.5 emissions (particulate matter less than $2.5 \mu$ in diameter); the impact of fire on air quality and the chemical transformation of fire emissions (Section 3.4); and plume behaviour based on PM2.5 concentrations as smoke (Section 3.5). The WRF-Sfire simulation of the 2012 Barker Canyon Fire, described in Section 4, is used to determine how well smoke as a passive tracer represents - at significantly less computational cost compared to a WRFSC fire and smoke simulation with full chemistry - the plume-rise and smoke injection heights (Section 4.2) that are currently either prescribed or supplied by simple smoke stack plume-rise algorithms. The results of the study are summarized and concluded in Section 5.

\section{WRFSC model description}

Fig. 1 illustrates how each operating component in WRF-Sfire and WRF-Chem couple to make up the integrated system WRFSC. The core of WRFSC is the WRF-Sfire model (Mandel et al., 2011), a two-way coupled fire-atmosphere model based on WRF (Skamarock et al., 2008). WRF-Sfire's atmosphere-fire coupling estimates fire spread based on local meteorological conditions, taking into account the feedback between the fire and atmosphere (Clark et al., 1996). WRF-Sfire also contains a fuel moisture model that predicts fuel moisture based on local meteorology (Mandel et al., 2014). WRF's nesting capabilities allow multi-scale domain configurations, where the outer domain, set at relatively low resolution, resolves the large-scale synoptic flow, while the gradually increasing resolution of inner domains provides representation of smaller and smaller scales required for realistic rendering of fire behaviour, fire convection, and smoke emissions. Coupling or feedback between inner and outer domains is two-way.

To accommodate high-resolution fuel and elevation data, and provide sufficient accuracy for the fire spread computation without increasing computational cost, Sfire operates on a separate surface model fire grid, refined significantly with respect to WRF's innermost domain grid. At every WRF time step, the near-surface wind from WRF is interpolated vertically to a logarithmic profile and 

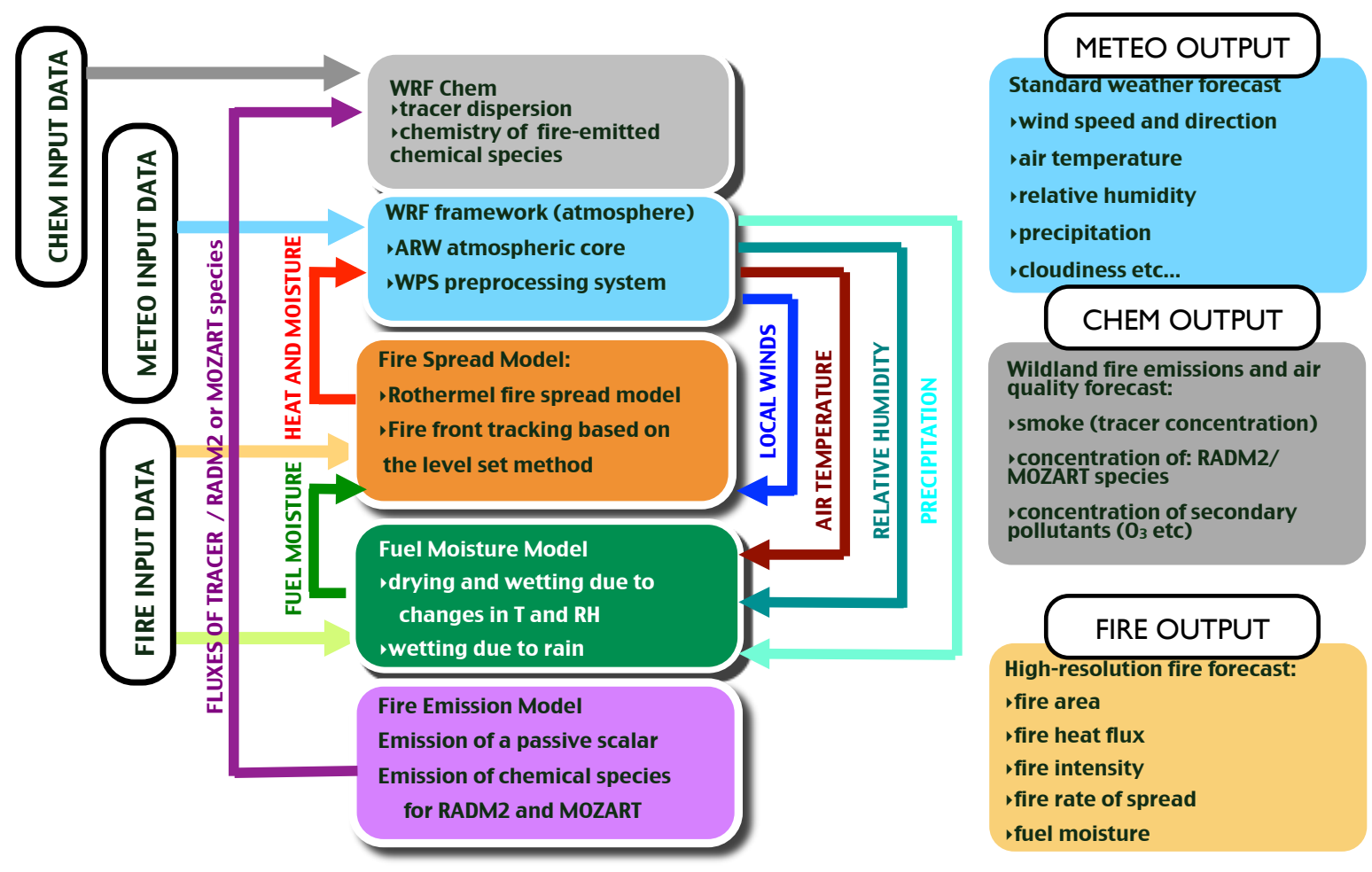

Figure 1: Diagram of WRF-Sfire coupled with fuel moisture model and WRF-Chem.

horizontally to the surface fire grid to obtain height-specific wind that is input into the Rothermel model (Rothermel, 1972) to determine the fireline's rate-of-spread. A fuel type is selected from the 13 categories in Anderson (1982). Each category includes a value for fuel mass, depth, density, surface-to-volume ratio, moisture of extinction, and mineral content. Based on these fuel properties and WRF-Sfire predicted winds, the surface fire-spread rate is computed at every refined mesh point. After ignition, the amount of fuel remaining is decreased exponentially over time, with the decay constant dependent on fuel properties following the BURNUP algorithm described in Albini (1994). The latent and sensible heat fluxes from the burning fuel are inserted into the lowest levels of WRF, assuming an exponential decay of the heat flux with height. A full description of the WRF-Sfire model can be found in Mandel et al. (2011). The current code and documentation are available from http://www.OpenWFM.org (Mandel, 2013). A version from 2010 is distributed with the WRF release as WRF-Fire (Coen et al., 2012; Mandel, 2012).

In the first step toward estimating smoke emissions, the Anderson fuel categories are converted into MODIS (Moderate Resolution Imaging Spectroradiometer) Land Cover Types (see Fig. 2) compatible with FINN global emission inventory (Wiedinmeyer et al., 2011). After this conversion, combustion rates are computed for each fire-grid point based on the mass of fuel consumed within one WRF time step. Once the fuel consumption is known, emission fluxes are computed as the products of the fuel-combustion rates and fuel-specific emission factors. The fire smoke emissions are then represented as a sum of fluxes of WRF-Chem-compatible chemical species listed in Fig. 2, which are ingested into the first model layer of WRF. 
Although WRFSC currently uses FINN global emission factors, the model accepts user-defined emission factors provided in one of the model configuration files. Since the FINN emission factors are compatible with the Model for Ozone and Related chemical Tracers (MOZART) (Emmons et al., 2010), when the MOZART emission scheme is used, the chemical fluxes computed as described above are fed directly into the chemistry model. The RADM2 chemical scheme is also supported, through remapping between the MOZART and the RADM2 chemical species (Emmons et al., 2010, their Table 7). Aside from the chemically reactive species, the FINN inventory allows estimates of emissions of particulate matter PM2.5 and PM10 which are integrated with the aerosol scheme as a part of WRF-Chem.

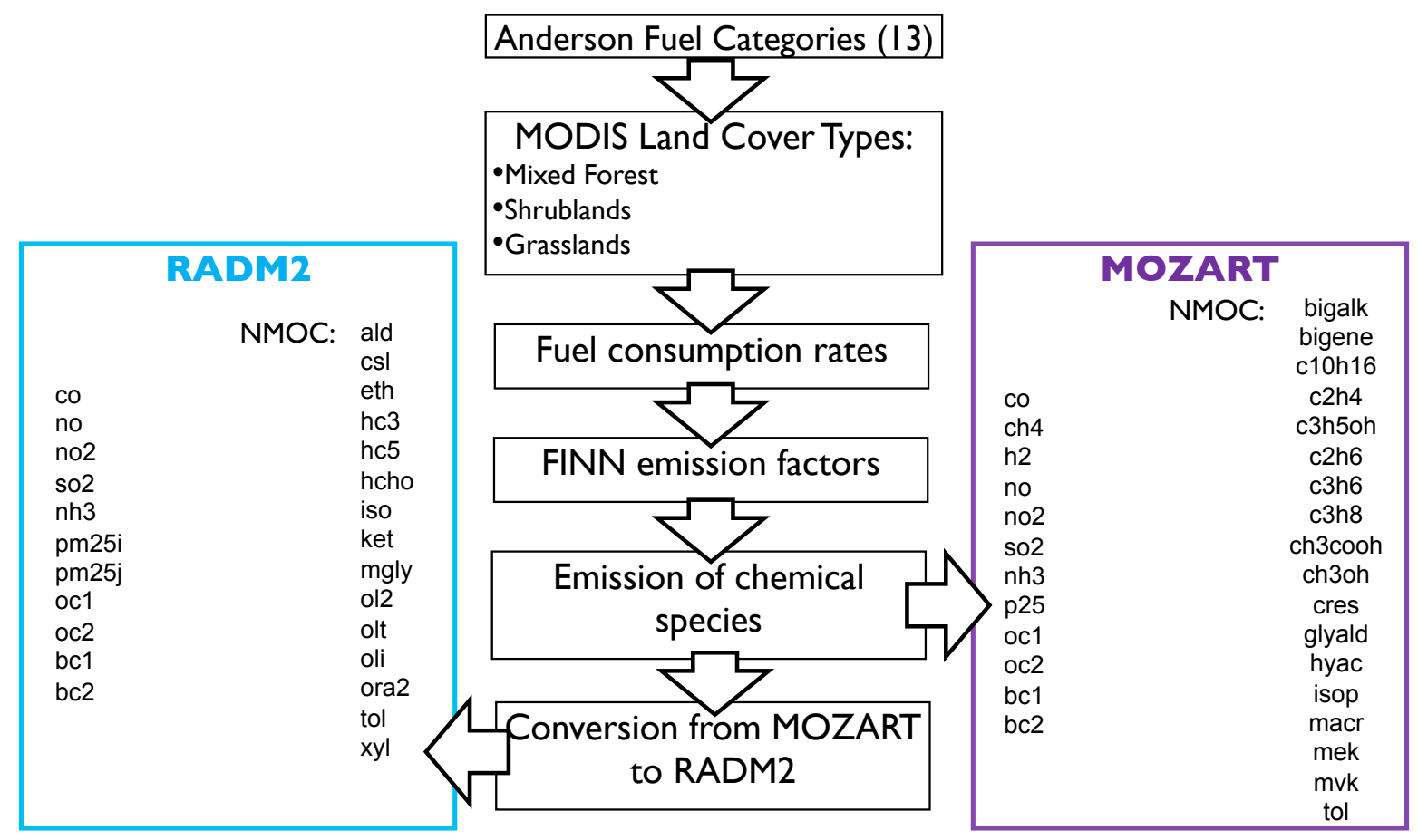

Figure 2: Computation of emissions in WRFSC.

However, the treatment of the smoke as a mixture of chemically active species undergoing chemical and physical processes in the atmosphere is very computationally intensive. In addition to the complex mathematical representation of the chemical reactions, each additional chemical species adds another three-dimensional scalar equation. As a consequence, computational time for a WRFSC simulation with full chemistry is roughly 3.6 times longer than for a WRF-Sfire simulation. To avoid this computational cost, another smoke generation mechanism was developed, in which fire smoke is represented simply as a passive scalar. Instead of resolving the concentrations of all chemical species listed in Fig. 2, the scalar field of passive, chemically-inert tracers is added to WRF-Sfire computations. As with emissions fluxes for WRFSC, the surface flux of the tracer is computed based on the product of the combustion rate and the user-specified emission factor. The execution of chemistry of fire-emitted chemical species in WRF-Chem is bypassed (see Fig. 1), and the WRF dynamical core handles transport of the passive smoke tracers directly. The passive smoke tracers do not undergo any chemical reactions and do not interact radiatively or physically with the 
WRF environment. This simple smoke representation adds only about $20 \%$ to the cost of running WRF-Sfire without a passive smoker tracer computation.

WRF-Chem contains a one-dimensional plume-rise module (Freitas et al., 2007) to distribute fire emissions vertically as part of WRF-Chem's preprocessing stage. The WRF-Chem plume-rise module releases about half of the fire emissions within the Atmospheric Boundary Layer (ABL) and releases the other half into the atmosphere from injection heights above the ABL (Pfister et al., 2011). Using realistic injection heights for fire emissions is considered fundamental to accurately simulating downwind transport and chemical evolution of fire plumes. The smoke injection height is sometimes referred to as the terminal height, based on the premise that the main detrainment (injection) mass layer of plume convection is situated close to plume top. With WRF-Sfire, however,

plume-rise and plume-top heights are predicted directly, at every WRF time-step, with no need of a plume-rise module.

\section{WRFSC 2007 Witch-Guejito fire simulation}

\subsection{Fire simulation setup}

The Witch fire was first discovered on 21 October 2007 at 12:29 pm local time near State Highway 78 and Santa Ysabel (degrees latitude and longitude: 33.109168, -116.673794). The Guejito fire was first discovered on 22 October 2007 at 1:00 am local time in the Guejito Creek drainage, on the south side of State Highway 78 and $402 \mathrm{~m}$ west of Bandy Canyon Road (degrees latitude and longitude: 33.093694, -116.961639). A weather station at the Ramona Airport showed that, at that time, the ambient temperature was $22^{\circ} \mathrm{C}$, the relative humidity was $6 \%$, and $15.6 \mathrm{~m} \mathrm{~s}^{-1}$ winds were from the east-north-east, gusting up to $19.7 \mathrm{~m} \mathrm{~s}^{-1}$ (Eidsmoe, 2007). The cause of both fires was thought to be arcing between power lines. Both fires, progressing during strong, warm, and dry easterly Santa Ana winds, burned a total 80,156 ha $\left(801.56 \mathrm{~km}^{2}\right)$, making these the largest fires in California for 2007.

The large-scale flow can interact with regional topography and land-use mosaic, creating specific local weather conditions that drive wildfire behaviour, which was the case in the Witch-Guejito fires. Therefore, in order to model development and movement of this large-scale weather system, including the Santa Ana winds it generated, together with the local circulation dictated by the complex topography of southern California, WRF was configured with four nested domains: D01, D02, D03, and D04, of horizontal-grid sizes $32 \mathrm{~km}, 8 \mathrm{~km}, 2 \mathrm{~km}$, and $500 \mathrm{~m}$, respectively. The model's vertically-stretch grid extended up to $15.4 \mathrm{~km}$, with a surface layer roughly $20 \mathrm{~m}$ thick and the top-most vertical layer roughly $2000 \mathrm{~m}$ thick. The surface fire mesh located in domain D04 had a refinement ratio of 25, making the horizontal fire-grid cell size $20 \mathrm{~m}$. Output from the fire simulation was saved every 10 minutes. The domain setup is shown in Fig. 3. The fire model, Sfire, used 30m-resolution elevation and fuel data, while the atmospheric model, WRF, used approximately $1.5 \mathrm{~km}$-resolution MODIS land-use representation. Further details of this setup can be found in Kochanski et al. (2013).

The Witch-Guejito test case was initialized and driven by the NARR (North American Regional Reanalysis) data (Mesinger et al., 2006), and run for a simulated time period of $48 \mathrm{~h}$ starting on 


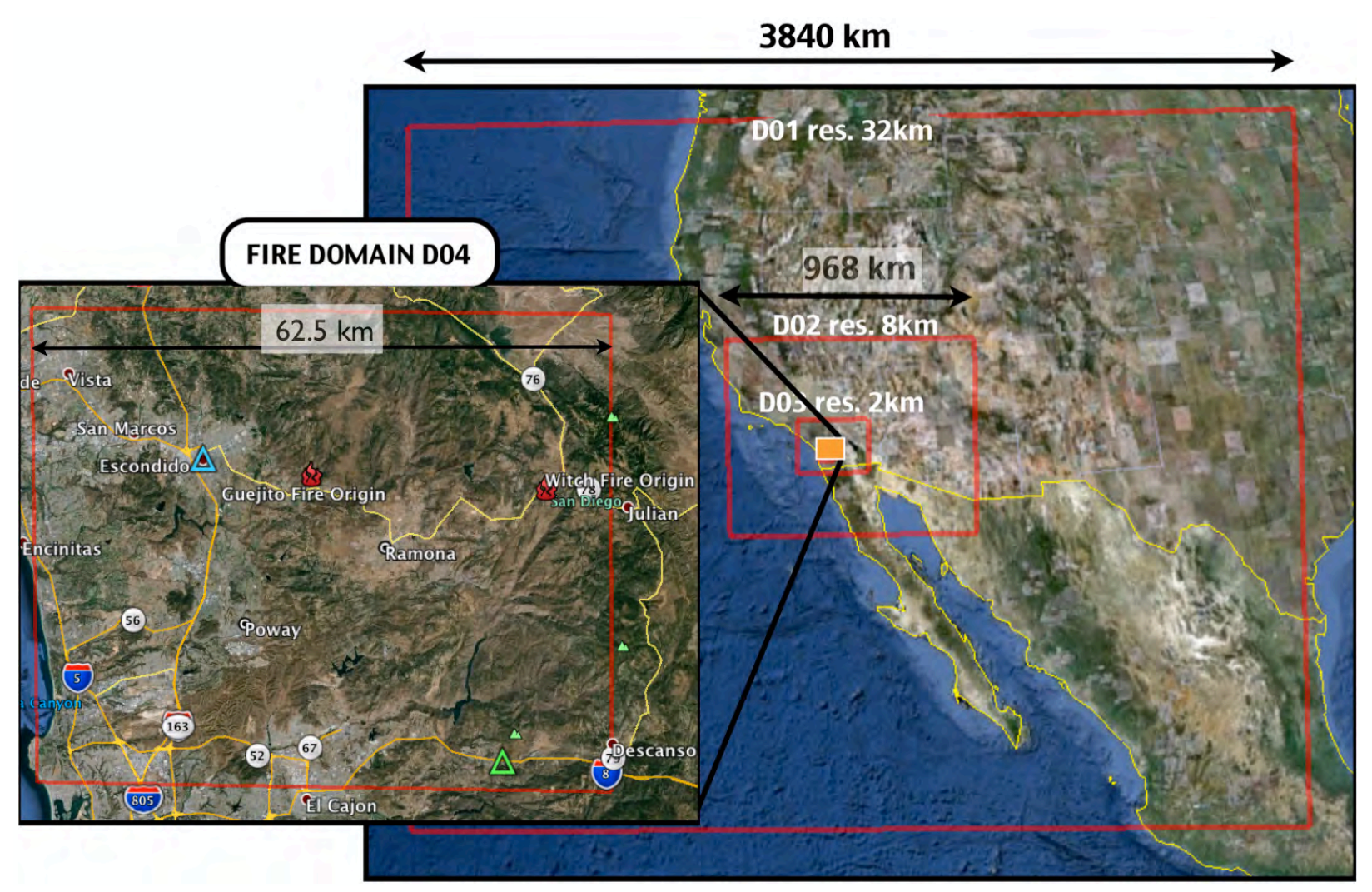

Figure 3: The multi-scale WRF setup in this study, including locations of the Witch and Guejito fire origins and the air quality stations used for model validation (Escondido - blue triangle; Alpine - green triangle). Horizontal domain resolutions vary from $32 \mathrm{~km}$ (D01) to 500m (D04). 
10.21.2007 5:00 am local time (12:00 UTC). The spatially-variable fuel moisture was initialized based on observations at the nearest weather station and then kept constant throughout the simulation. The observed relative humidity was extremely low and, along with the dry and warm Santa Ana winds, inhibited fuel moisture recovery.

The Witch Fire was ignited in the Witch Creek area east of Ramona, California, almost 7h into the simulation. Both fires were initialized as point ignitions, and allowed to spread freely across the fuel mosaic driven by WRF-modelled local winds. The $48 \mathrm{~h}$ simulation was done without updating the model state with current meteorological observations during the run. The WRF was provided with boundary conditions only at the initial stage and was not nudged towards the observations. This means that, unlike an actual operational forecast during which the WRF state is updated as the most current meteorological observations are assimilated, we did not interfere with WRFSC as it ran. A detailed description of model configuration and datasets used for model initialization, as well as a comparison between the simulated and observed fire progression, are found in Kochanski et al. (2013).

To isolate the impact of the simulated fire on the air quality, no other chemical emissions were specified; i.e., WRFSC did not use the chemical boundary conditions and the standard idealized chemical profiles provided by WRF-Chem for chemical initialization. The 48h WRFSC simulation with MOZART chemistry took $29 \mathrm{~h} 56 \mathrm{~min}$ on 324 CPUs of the University of Colorado Janus cluster (https://www2.cisl.ucar.edu/resources/janus).

\subsection{PM2.5 dispersion inside fire domain D04}

Bulk particulate matter PM2.5 was used to represent the dispersion of pollutants emitted from the WRFSC simulated Witch-Guejito fires. Not all the particulate matter in the simulation corresponded to that released from the Witch-Guejito fires. WRFSC-generated background PM2.5 concentration was present. To distinguish between fire and non-fire PM2.5, a PM2.5 threshold of $1 \mu \mathrm{g} \mathrm{m}^{-3}$ was subtracted from the PM2.5 concentrations. This threshold was found to be the lowest concentration that filtered out the background concentrations of PM2.5 without losing the fire signal from the freshly emitted PM2.5.

Fig. 4 shows the PM2.5 concentration results used to visualize smoke emissions from the WitchGuejito fire. The Santa Ana wind blowing from east-north-east, at a speed of up to $19 \mathrm{~m} \mathrm{~s}^{-1}$ (68 $\mathrm{k} \mathrm{h}^{-1}$ ), with little variation in direction, rapidly pushed the Witch fire toward Encinitas and, 1 hour after ignition, confined the smoke to a long narrow downwind trajectory (Fig. 4a). Fig. 4b depicts smoke emissions 6 hours after ignition. Since WRFSC estimates emissions based on the combustion rate, emissions within the fire perimeter were not uniform. Smoke production was rapid and significant at the head of the fire and along the forward flanks, while inside the fire perimeter, where available fuel was depleted, emissions and smoke production were lower. As the fire progressed and its flanks expanded, the plume footprint also widened. The area affected by smoke was much larger than that in Fig. 4a. Fig. 4b shows how a slight change in wind direction in the western half of the fire domain pushed the smoke much further south compared to the previous result in Fig. 4a, with smoke covering a big part of the southwestern corner of fire domain. Note the sharp southeastern edge of the plume where steep canyons channeled the flow, limiting lateral smoke dispersion. 


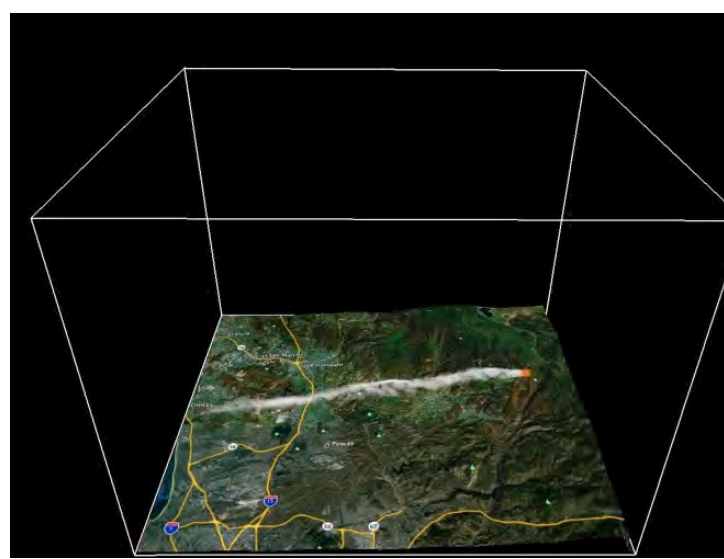

a) 10.21.2007 13:15 local time $1 \mathrm{~h}$ after ignition of the Witch fire

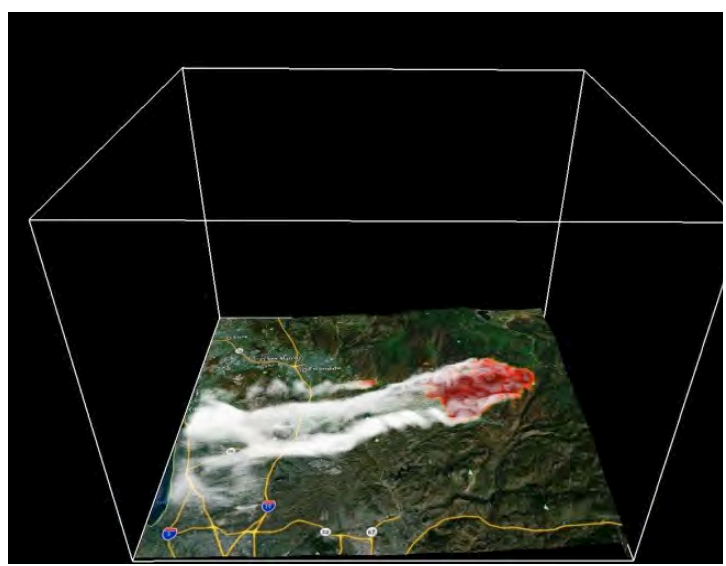

c) 10.22.2007 03:00 local time $2 \mathrm{~h}$ after ignition of the Guejito fire

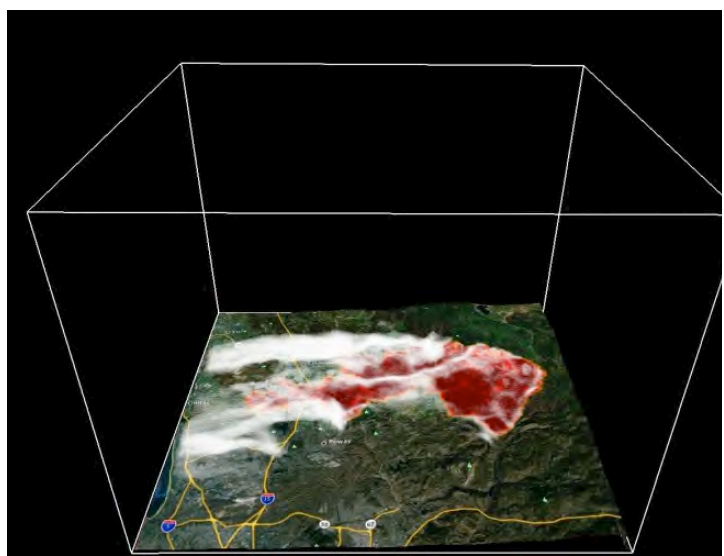

e) 10.22.2007 17:00 local time $36 \mathrm{~h}$ into simulation

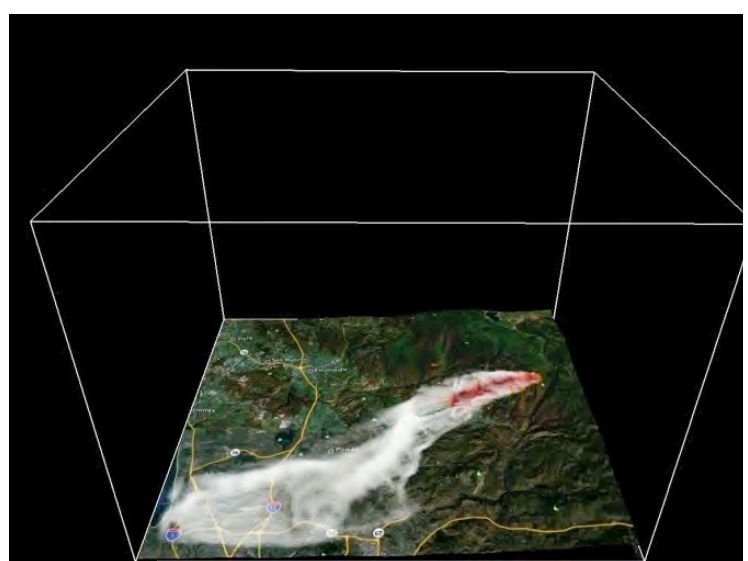

b) $10.21 .2007 \quad 18: 15$ local time $6 \mathrm{~h}$ after ignition of the Witch fire

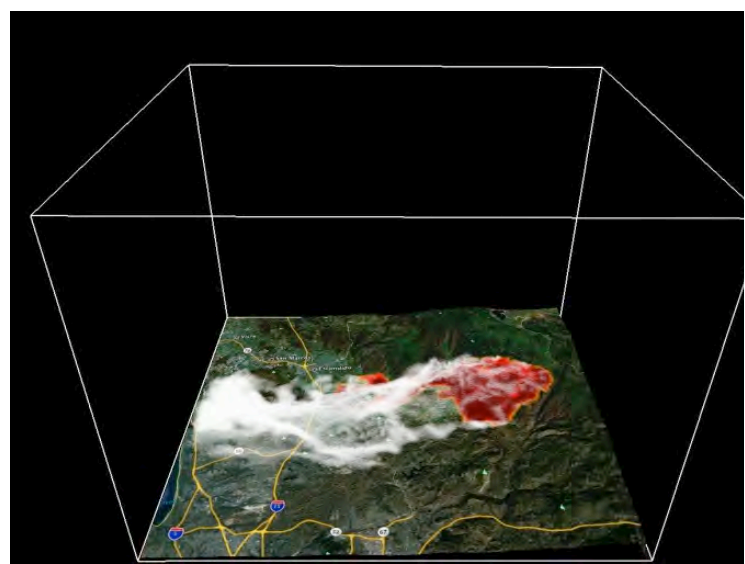

d) 10.22.2007 06:00 local time $5 \mathrm{~h}$ after ignition of the Guejito fire

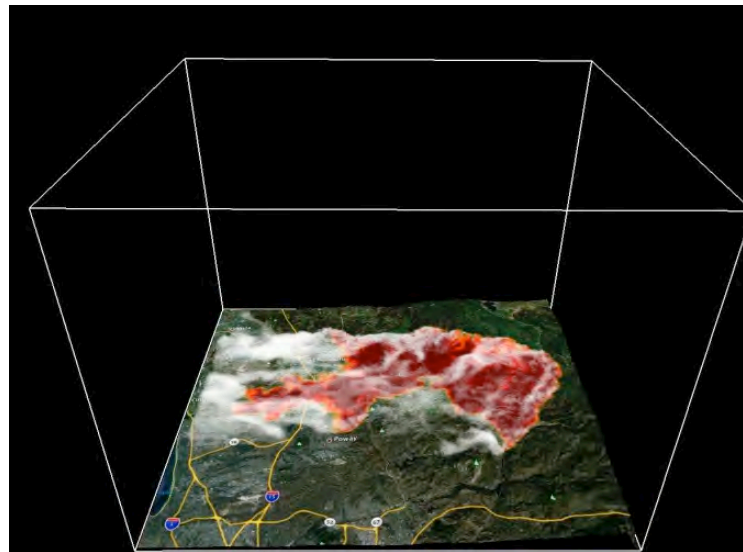

f) $10.23 .200705: 00$ local time $48 \mathrm{~h}$ into simulation

Figure 4: Depiction of the Witch and Guejito fires at six different times in domain D04 of the simulation. Smoke, shown in white, is represented PM2.5 minus a background threshold PM2.5. See text for further explanation. Dark red fill represents burned-out fire area and orange fill shows active fire. 


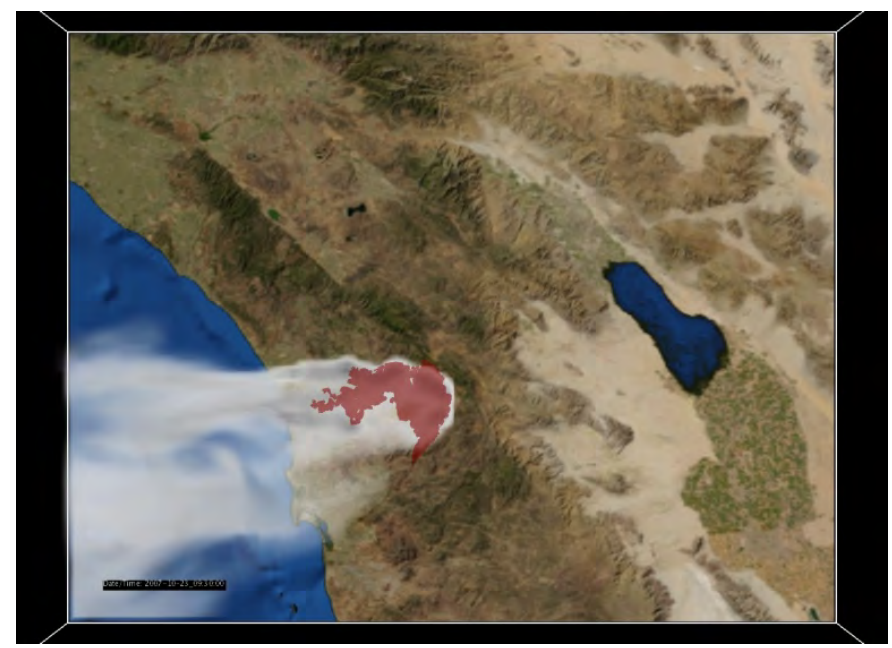

(a) WRF domain D03 at time 10.23.2007 UTC

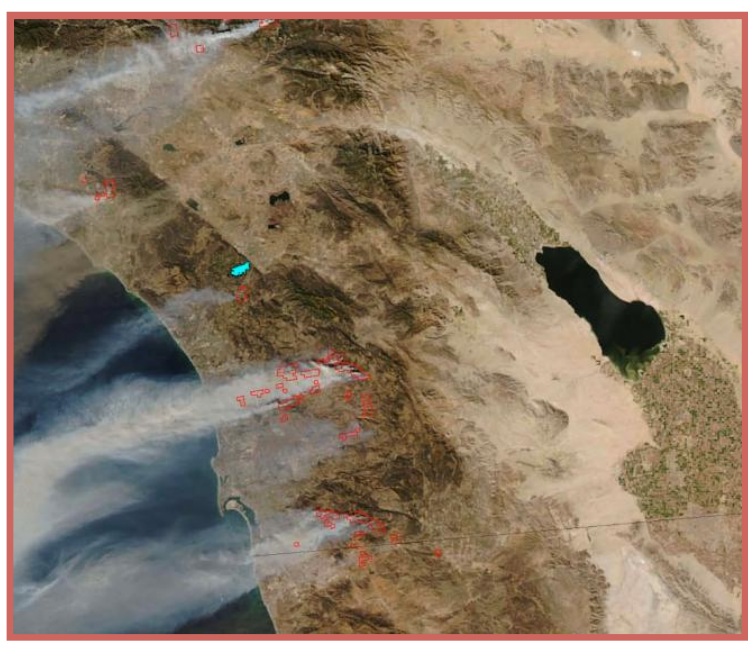

(b) MODIS image at time 10.23.2007 UTC

Figure 5: Smoke dispersion within domain D03 (2km resolution) simulated by (a) WRFSC and (b) MODIS satellite image. The red color fill in (a) represents the fire area projected from the nested fire domain D04 (500m resolution). Red contours in (b) represent remotely detected hot spots (regions of the highest fire intensity).

Fig. 4c shows the fire perimeters and smoke propagation two hours after ignition of the Guejito fire. Smoke plumes from the two fires were separate, and even though the Guejito fire was much smaller, its contribution to the overall smoke pall is clearly visible in the southern part of Escondido. As both fires expanded and approached each other, their plumes combined (Fig. 4d) before the actual fire perimeters merged. Note the non-homogeneous smoke production at that moment. As the Witch fire approached Ramona (see Fig. 3 for location), its western edge became relatively inactive (Fig. 4e), which reduced smoke in that region. At the same time, there were two distinct smoke plumes, one formed by the Guejito fire and the northern flank of the Witch fire, and the second formed primarily by the southwestern head of the Witch fire. Fig. 4f presents the situation at the end of the simulation after both fires merged. The former Guejito fire extended several kilometers southward and became a strong source of fire emissions affecting the Poway area (see Fig. 3 for location). Interior areas of active fire, as well as those along the eastern edge of the Witch-Guejito fire, contributed to the overall smoke pall. Fig. 4f shows a very complex fire and smoke emissions pattern. The wind continued to push the fire westward, with multiple hot spots all along the perimeter as well as within the interior.

How well the final perimeter of the $48 \mathrm{~h}$ WRF-Sfire Witch-Guejito simulation compared to the observed final fire perimeter is shown in Kochanski et al. (2013, their Fig. 8). Although the agreement between observed and simulated final fire perimeters was relatively good overall, there were discrepancies, such as in the residental region north of Escondido, which was burnt in the WRF-Sfire simulation but not in reality. (This is relevant to the results shown in Fig. 6 in Section 3.4.) 


\subsection{PM2.5 dispersion outside fire domain}

WRF's two-way coupling between multiple domains is used to transfer the PM2.5 smoke plume from the innermost, high-resolution fire domain to the coarser resolution outer domains to resolve large-scale smoke transport. An example of PM2.5 smoke dispersion within model domain D03 (2km resolution) is shown in Fig. 5a. Fig. 5b presents the corresponding satellite image from MODIS where estimates of active fire area obtained from MODIS fire radiative power (FRP) thermal anomalies are compared to the modelled fire perimeter. The MODIS image in Fig. 5b includes smoke plumes produced from all fires in the region, while Fig. 5a shows only the smoke from the WRFSC simulation of the Witch-Guejito fires. Nonetheless, there is at least a visible resemblance between the WRFSC simulated and MODIS-observed smoke dispersions. The aerial extent of each smoke plume is similar, and even some of the MODIS smoke dispersion features off the coast of San Diego are captured by WRFSC. The hot spots in the MODIS image in Fig. 5b seem to be co-located along the simulated fire perimeter presented in Fig. 5a.

\subsection{Fire impact on local air quality}

WRFSC's ability to represent concentrations of NO and fire-emitted fine particulate matter PM2.5 is shown in Fig. 6. The PM2.5 and NO fluxes are primary pollutants, emitted directly into the atmosphere from active fire grid points according to local fuel consumption rates and fuel-specific emission factors. Time series of 10-minute model output (marked with Xs) show PM2.5 concentrations greater than observed and NO concentrations less than observed. The 1h-running means of simulated PM2.5 concentrations for the Escondido station reached values close to those observed (450 versus $475 \mu \mathrm{g} \mathrm{m}^{-3}$ ), while the $1 \mathrm{~h}$-running means of simulated NO concentrations were significantly lower in magnitude compared to observations (38 ppb versus $60 \mathrm{ppb}$ ). WRFSC-predicted values peaked a couple of hours earlier than observed values. The time shift between observed and simulated peaks can possibly be attributed to an overestimation in the north-west fire progression toward Escondido. Kochanski et al. (2013) determined that the simulated fire progressed approximately $10 \mathrm{~km}$ further in the north-west direction than the actual fire.

In as complex a modelling system as WRFSC, it is not possible to determine directly every reason for the discrepancies between the simulated and observed NO levels seen in Fig. 6b. One reason may be that the three MODIS Land Cover Types (i.e., mixed forest, shrublands, and grasslands) are not detailed enough to represent the chemical smoke composition from fires spreading across 13 different Anderson fuel-bed categories. Another reason may be that WRF-Chem's global NO emission factors for grass and shrubs may be slightly lower than the actual NO emission factors for the fuel types in the Witch-Guejito region of Southern California. Nonetheless, these differences between PM2.5 and NO simulated and observed are relatively low, and show promise for improved fire-emissions forecasts.

Integration of WRF-Sfire with the WRF-Chem chemistry modules should also capture the chemical plume transformation in the atmosphere, that then represents the effect of smoke on secondary pollutants, such as ozone. A test of WRFSC's ability to represent ozone concentrations is presented in Fig. 7. The locations of Escondido and Alpine air quality stations used in this study are shown in Fig. 3 (blue and green triangles). 


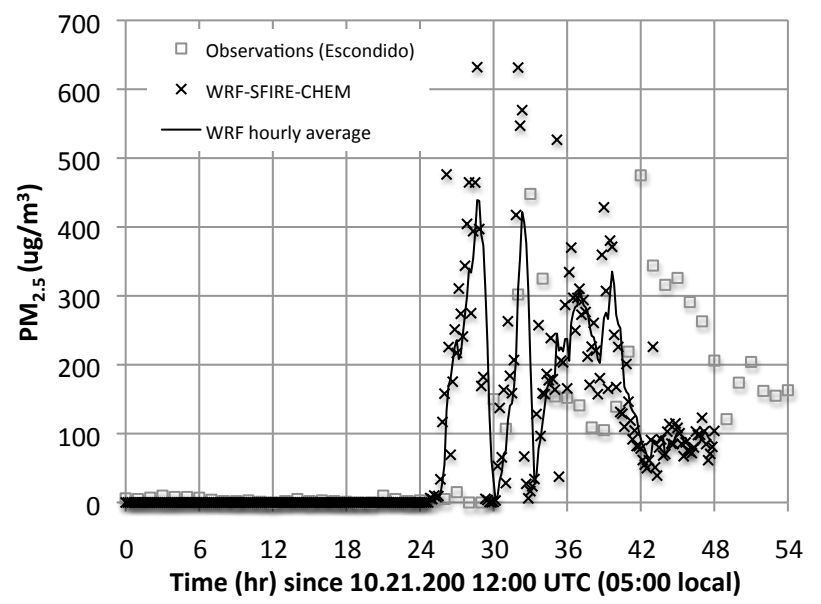

(a)

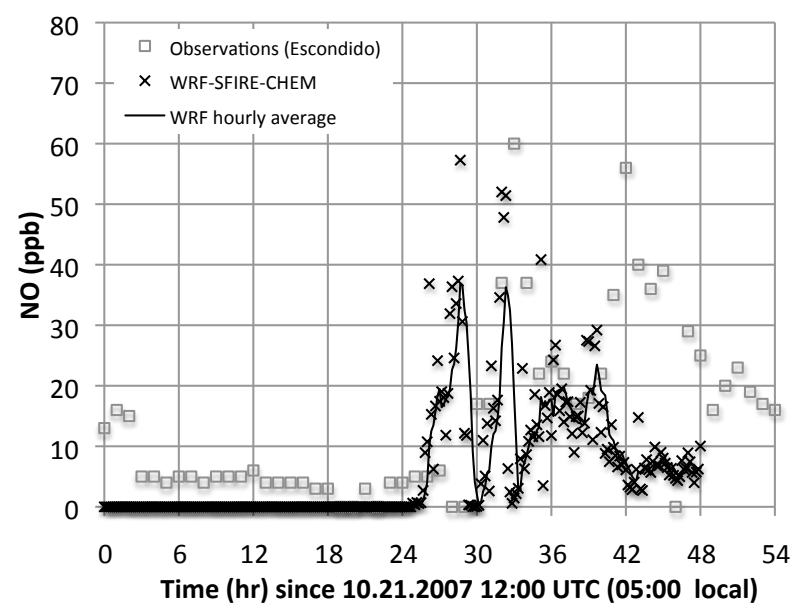

(b)

Figure 6: Time series of the (a) PM2.5 $\left(\mu \mathrm{g} / \mathrm{m}^{3}\right)$ and (b) NO (ppb) simulated by WRFSC and observed by the Escondido air quality station. 
Surface ozone measurements are affected by other emissions, such as traffic, biogenic, and emissions from other fires, that were not included in the WRFSC simulation. As described in Section 2, the chemical component of WRFSC was set up in a simplified way, neglecting all anthropogenic and biogenic emissions, except those from the simulated fire, and the WRFSC fire simulation was started with zero ozone. Therefore, when comparing the modelled to surface-station ozone observations shown in Fig. 7, the focus is on differences in amplitudes, rather than absolute values, of the firerelated peaks in ozone concentrations. The time series of surface ozone concentrations in Fig. 7 are plotted using dual vertical axes. For easier comparison between the observed and simulated ozone peaks, both axes are scaled similarly, but the axes for observed ozone concentrations start at pre-fire values of 45 and $40 \mathrm{ppb}$, while the axis origin for the simulated results starts at 0 . The pre-fire values of 45 and $40 \mathrm{ppb}$ in Fig. 7 match well the pre-fire ozone concentrations range of 40.1 to 44.5 ppb estimated by Bytnerowicz et al. (2010).

Fig. 7a shows that the simulated fire-caused peak in ozone concentration at the Alpine station was lower in magnitude than the observed one. Observations indicate a $21 \mathrm{ppb}$ increase in the ozone concentration, while simulated ozone increased by $16 \mathrm{ppb}$. Fig. 7b shows that the underestimation of ozone concentration by WRFSC is even more evident at the Escondido station. Measurements indicate an increase of about $27 \mathrm{ppb}$ while modelled ozone concentration peaked at $16 \mathrm{ppb}$. The exact reason for these discrepancies is hard to identify. It is possible that the underestimation in the fire emissions of precursor NO (Fig. 6) contributed to this problem. Simulated ozone peaks are also delayed compared to the observations. Station measurements show ozone concentrations peaking late in the morning in Alpine and early afternoon in Escondido, while modelled ozone concentrations peak later in the evening.

We lack the observational data to determine if the fire emission inventory is represented correctly, making further analysis of the chemical mechanisms in the chemistry component of WRFSC beyond the scope to this work. It is possible that the discrepancies between simulated and observed results shown Fig. 6 may be partly due to the simplified chemical setup used in this study and that the simulation period was too short for the chemical model to spin up. Also, WRF-Sfire accounts for flaming emissions only, and smoldering emissions are neglected.

\subsection{Plume-top heights based on PM2.5 concentrations}

AGL (Above Ground Level) plume-top heights based on PM2.5 were calculated for each 10-minute model output and grid column in D04 $(62.5 \mathrm{~km} \times 52.5 \mathrm{~km})$ with fire PM2.5 present. The plumetop heights were then averaged over 6 -h time intervals representing night (10:00pm to 4:00am local time) and day (10:00am to 4:00pm local time) time periods. These 6 -h averages are shown in the left column of Fig. 8, where row A are the night plume-top heights of 21 October, row B are the day plume-top heights of 22 October, and row $\mathrm{C}$ are the night plume-top heights of 22 October. The middle column gives the corresponding standard deviations for these same time periods. The right column shows a single snapshot of the plume-top heights at 3 hours into each 6 -hr averaged time period. The corresponding burned area for each time period is shown in black.

The left and right columns in Fig. 8 shows strong spatial and temporal variability in plume-top heights with maximum values between 1100 to $2200 \mathrm{~m}$ AGL downwind of the fire and increasing in magnitude as the fire grew in size. Maximum plume-top heights were: $1329 \mathrm{~m}$ (top left); 1709 


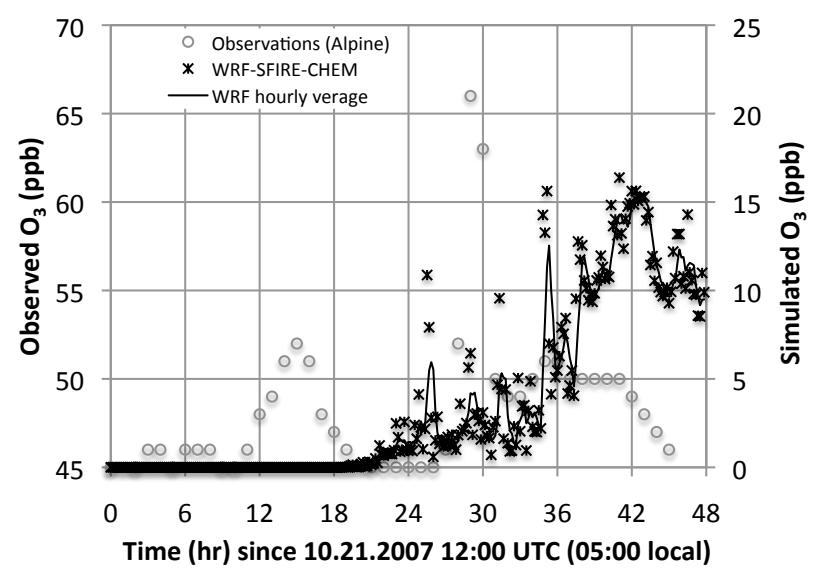

(a)

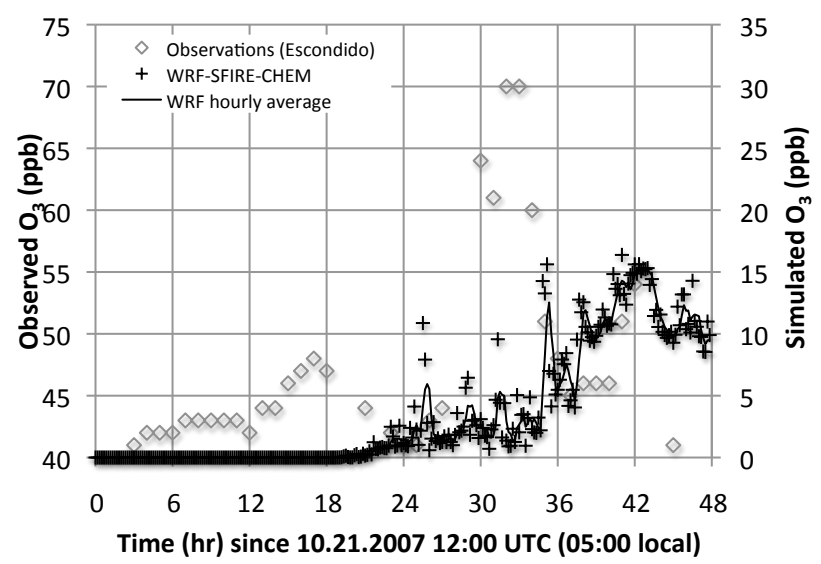

(b)

Figure 7: Time series of WRFSC simulated and of observed ozone concentrations at air quality stations (a) Alpine and (b) Escondido. Plus signs (+) denote 10-minute WRFSC output values, solid line denotes $1 \mathrm{~h}$ running-means of WRFSC 10-minute output values. 
(middle left); 1159 (bottom left); $1291 \mathrm{~m}$ (top right); 2163 (middle right); 1898 (bottom right). The middle column shows that the standard deviations of the time-averaged heights were often as large as $600 \mathrm{~m}$, also indicating considerable variation over each 6-hr period from particular portions of the fire perimeter. Fig. 8 illustrates clearly the non-Gaussian horizontal spread of fire plume. Plots, like those in the right column, but for the entire simulation (not shown), captured multiple plumerise peaks, associated with multiple plume updraft cores, a phenomenon known to occur often in wildland fires (Goodrick et al., 2012). Based on these results, it may not be accurate to represent the plume and fire emissions of a propagating wildfire in terms of a single Gaussian-shaped plume and terminal or plume-ejection height.

Plume-rise models, such as Freitas et al. (2007, 2010), used to simulate injection heights in CTMs (Chemical Transport Models), require as input temperature and wind-speed profiles in order to determine the vertical distribution of fire emissions in the atmosphere near the fire source (i.e., injection heights). Fig. 9 shows the temperature, wind-speed, and fire emission profiles for the WRFSC Witch-Guejito fire. Vertical profiles of the near-fire 6-hr averaged temperature (left column, blue) and wind speed (middle column, light red), as well as domain-averaged PM2.5 (right column, red) for the (A) night of the 21st, (B) daytime of the 22nd, and (C) night of the 22nd are given. Close to the fire means locations upwind of the burn area, and therefore not influenced by the burn, with a displacement of roughly one horizontal WRF grid cell away from the burn area.

Vertical profiles of daytime 6-hr averaged ambient temperatures (Fig. 9 B1) show elevated surface temperatures compared to the nighttime surface temperatures on the first, pre- Santa Ana day (Fig. 9 A1), but very similar to the nighttime temperatures during the Santa Ana event (Fig. 9 C1). The temperature profiles also show daytime-nighttime variation in both height and strength of an inversion layer topping the atmospheric boundary layer. The 6-hr averaged vertical wind speed profiles (Fig. 9 B-C 2) show a surface jet below $500 \mathrm{~m}$ AGL, descending toward the surface, and causing strongest overall wind speed magnitude and variability during the daytime (Fig. 9 B2). Both the nighttime and daytime vertical profiles for PM2.5 (Fig. 9, right panels) shows surface PM2.5 concentrations exceeding the daily EPA standards of $35 \mu \mathrm{g} \mathrm{m} \mathrm{m}^{-3}$.

The smoke injection height, sometimes known as the terminal height, is fundamental to accurately representing fire emissions in CTMs (Val Martin et al., 2012), and the vertical distribution of fire emissions (if available) is used to locate the smoke injection height. Fig. 9, column 3, does not however, indicate a single, simple terminal plume height. The PM2.5 profiles indicate instead, depending on the PM2.5 concentration cutoff or decay rate used, a range plume-ejection heights between 1000 to $1500 \mathrm{~m}$ AGL. And this range matches the range of plume-top heights found in Fig. 8. Based on the PM2.5 profiles, the minimum plume injection height is assumed to be approximately $1000 \mathrm{~m}$ AGL.

The MISR (Multi-angle Imaging SpectroRadiometer) satellite data retrieval during the time period of the Witch-Guejito WRFSC simulation was also used to evaluate the WRFSC's ability to represent plume-top heights. There was no MISR retrieval for the Witch-Guejito fire. Plume height estimates based on available MISR data satellite retrievals of two wildland fires in the vicinity of the WitchGuejito fire during the time period of the simulation are given in Table 1. A straightforward averaging of the MISR plume heights in Table 1 gives an average median plume height of 814 $\mathrm{m}$ and an average standard deviation $292 \mathrm{~m}$, and an average plume-top height of $1236 \mathrm{~m}$ and 

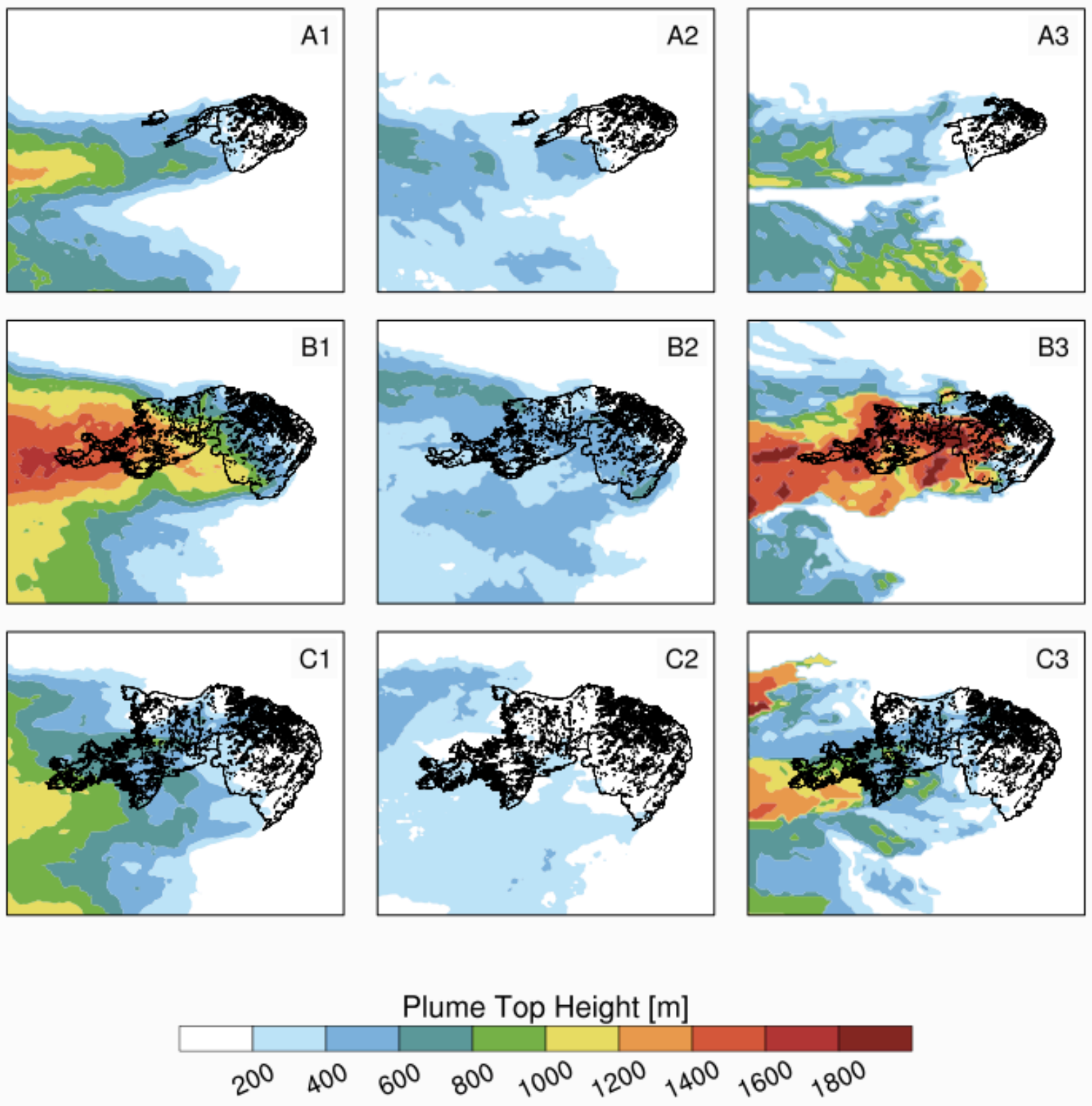

Figure 8: The rows depict three time frames during the WRFSC Witch-Guejito simulation: (A) night of the 21st; (B) daytime of the 22nd; and (C) night of the 22nd. The columns, from left to right, represent the: (1) 6-hr averaged plume-top heights; (2) standard deviations of 6-hr averaged plume-top heights; and (3) a snapshot of plume-top height 3 hours into each 6 -hr time frame. The burned area for each time period is outlined in black. The plots cover domain D04 (62.5 x 52.5 $\mathrm{km})$. 


\begin{tabular}{|c|c|c|c|c|c|c|c|}
\hline Longitude & Latitude & $\begin{array}{c}\text { Plume } \\
\text { Perimeter } \\
\text { Length } \\
{[\mathrm{m}]}\end{array}$ & $\begin{array}{c}\text { Plume } \\
\text { Area } \\
{\left[\mathrm{km}^{2}\right]}\end{array}$ & $\begin{array}{c}\text { Median } \\
\text { Plume } \\
\text { Height } \\
{[\mathrm{m} \text { AGL }]}\end{array}$ & $\begin{array}{c}\text { Top } \\
\text { Plume } \\
\text { Height } \\
{[\mathrm{m} \text { AGL }]}\end{array}$ & SDev & FRP \\
{$[\mathrm{m}]$} & MW \\
\hline \hline-117.441 & 33.244 & 70 & 259 & 943 & 1260 & 269 & NA \\
-116.562 & 32.623 & 269 & 2168 & 684 & 1017 & 314 & 1061 \\
\hline
\end{tabular}

Table 1: MISR plume retrieval data for wildfires in the vicinity of Witch-Guejito fire on date 200710-21 and time 18:39:52 UTC. SDev = Standard Derivation. FRP = Fire Radiative power. MW $=$ Megawatts. See text for details.

an average standard deviation of $379 \mathrm{~m}$. These results compare well to range of the simulated plume-top heights (1000 to 1500 m AGL) suggested by Figs. 8 and 9.

Fig. 10 is similar to Fig. 8 except that it illustrates the impact of a threshold background level PM2.5 on plume-top height calculations. Different filter quantities were tested, and the plume-top heights shown in Fig. 10 indicate that a PM2.5 filter in a range from $0.1-10 \mu \mathrm{g} \mathrm{m}^{-3}$ assure robust plume-top heights estimates insensitive to the particular value of the threshold. Maximum plume top height was $1574 \mathrm{~m}$ for all PM2.5 filters $\leq 1.0 \mu \mathrm{g} \mathrm{m}^{-3}$, but $1092 \mathrm{~m}$, almost $500 \mathrm{~m}$ lower, for PM2.5 filter $10.0 \mu \mathrm{g} \mathrm{m}^{-3}$.

\section{WRF-Sfire 2012 Barker Canyon fire simulation}

\subsection{Fire simulation setup}

The high computational costs and the discrepancies between observed and modelled ozone estimates for the Witch-Guejto WRFSC simulation indicate that WRFSC fire and smoke simulations with full chemistry are not yet practical. When only plume-top height estimates are needed and chemistry and smoke dispersion are handled by an external chemistry model, running WRFSC, the full coupled version of WRF-Sfire-Chem, is not necessary. Here we present the results of a WRF-Sfire simulation of the 2012 Barker Canyon fire, where fire smoke is represented by passive (non-reactive) tracers, as opposed to a mixture of chemically reactive species.

The Barker Canyon fire was ignited on 09.08.2012 by a series of lightning strikes in its northern branch around 19:20 and its southern branch around 20:00 local time (Figure 11). The two fires within the complex grew dramatically during a wind event over September 10-11 burning a total area of 32,842 ha $\left(328.42 \mathrm{~km}^{2}\right)$ by September 19 .

The Barker Canyon fire simulation used 5 nested domains of resolutions from $36 \mathrm{~km}$ to $444 \mathrm{~m}$ (i.e., $1 / 3$ grid ratio) (Fig. 11 and Table 4.1). The fire model mesh refinement was set to 20 for the innermost fire domain (i.e., $22.2 \mathrm{~m}$ resolution). The NARR reanalysis supplied boundary conditions to WRF throughout the simulation. High resolution topography and fuel data (at $30 \mathrm{~m}$ resolution), available from Landfire (http://www.landfire.gov), were used by Sfire, the fire component of the system. Initial fuel moisture in the $1 \mathrm{~h}$ class was computed following Van Wagner and Pickett (1985) 

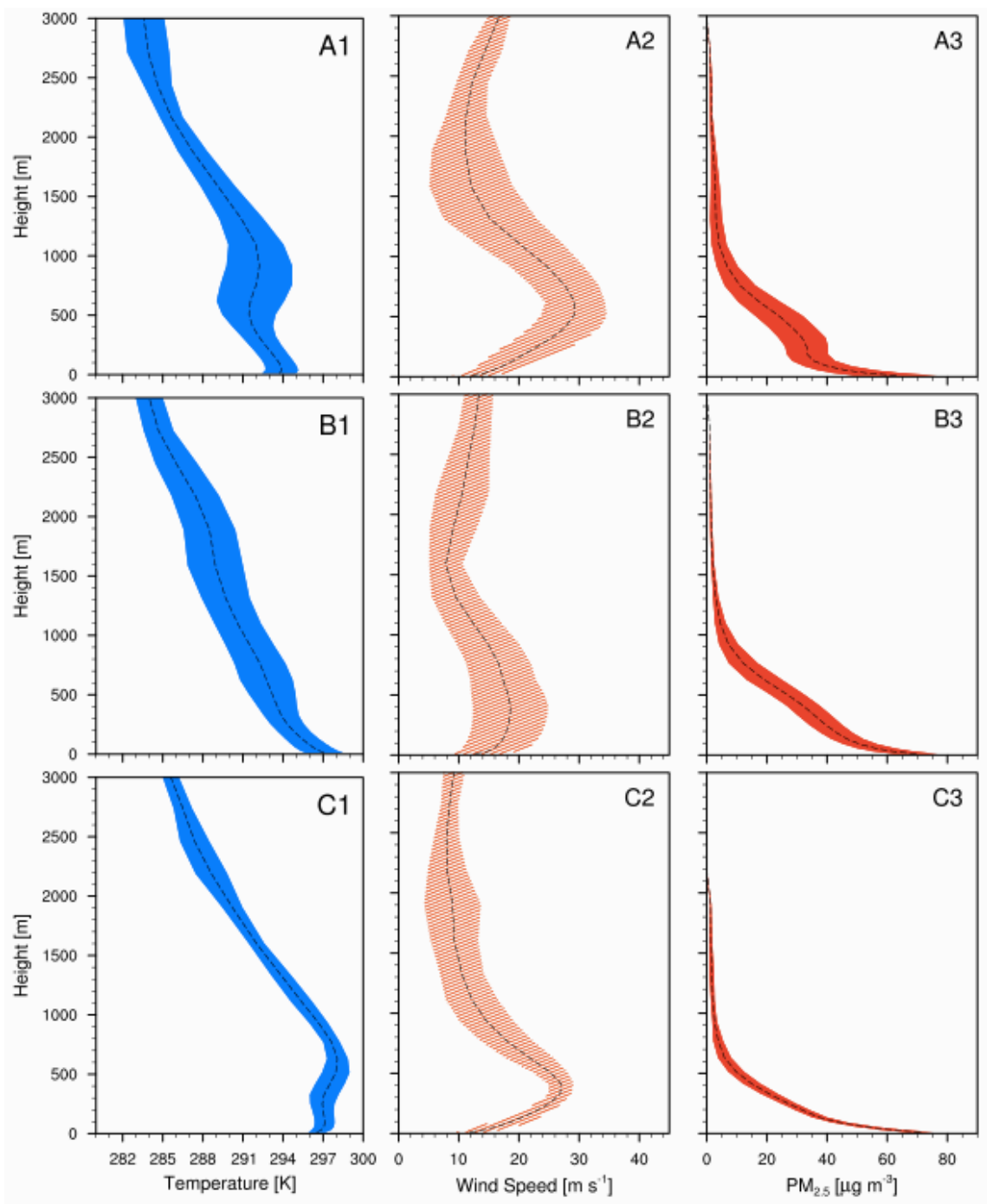

Figure 9: Vertical profiles of 6-hr averages of temperature (left column), wind speed (middle column), and total PM2.5 concentrations (right column) for night of the 21st (top row), daytime of the 22nd (middle row), and night of the 22nd (bottom row). PM2.5 concentrations $\leq 1.0 \mu \mathrm{g} \mathrm{m}^{-3}$ were omitted from PM2.5 averages, and the height is AGL. See text for further details. 

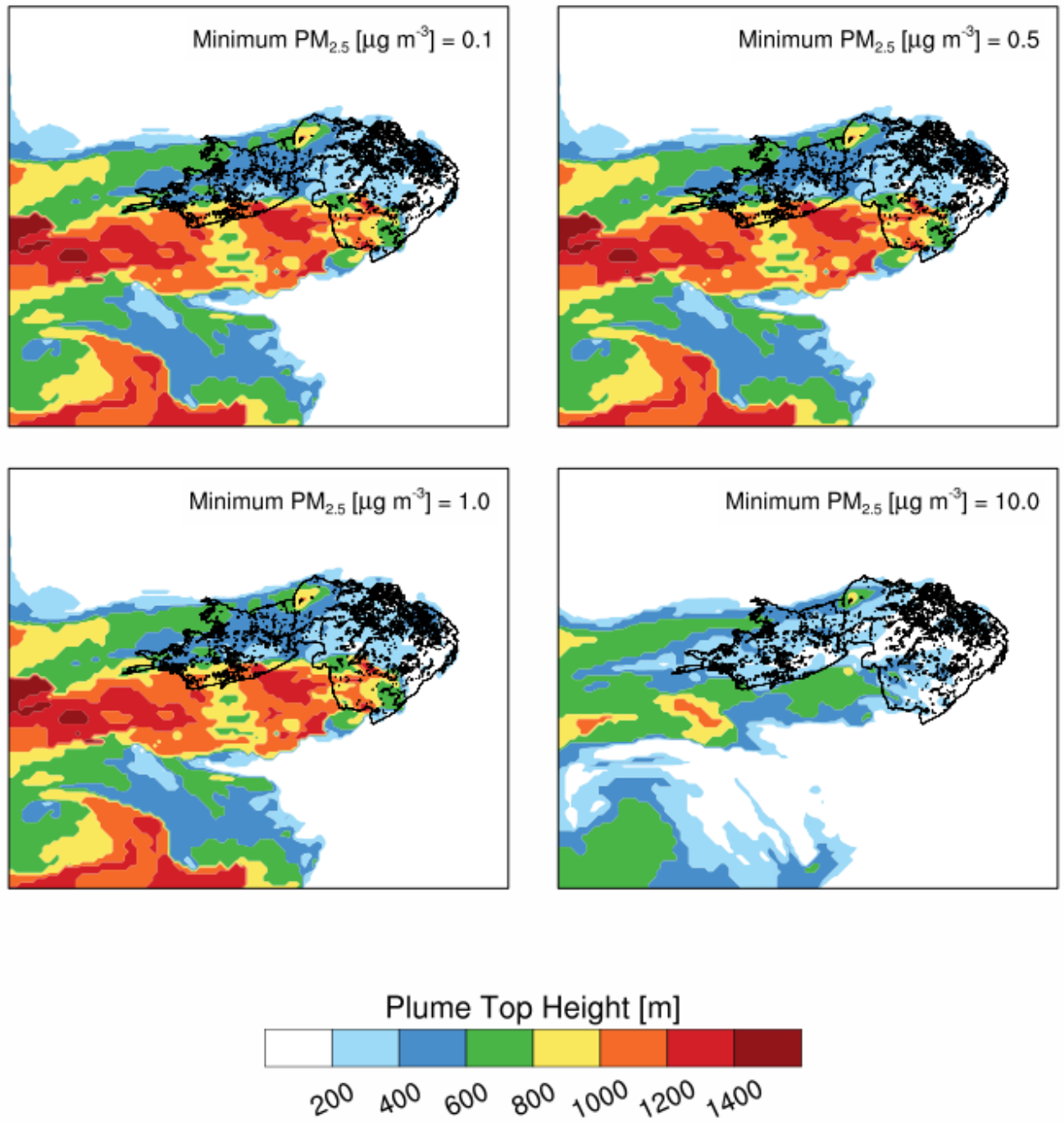

Figure 10: Contours show the 6-h averaged maximum plume top heights for the Witch-Guijito WRFSC simulation based on four minimum PM2.5 filters: upper left $0.1 \mu \mathrm{g} \mathrm{m}^{-3}$; upper right 0.5 $\mu \mathrm{g} \mathrm{m}^{-3}$; bottom left $1.0 \mu \mathrm{g} \mathrm{m}^{-3}$; bottom right $10.0 \mu \mathrm{g} \mathrm{m}^{-3}$. 


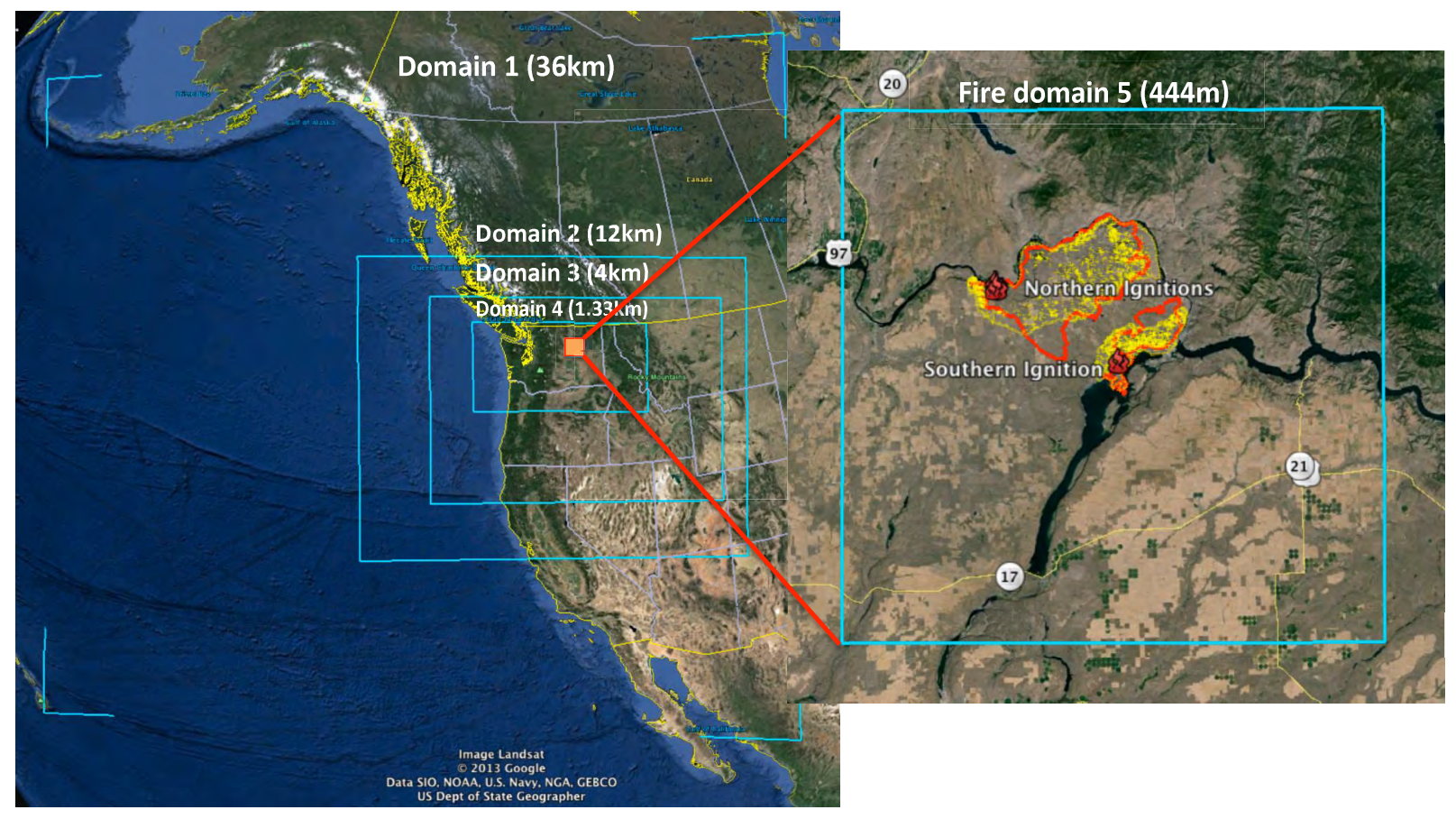

Figure 11: Domain setup used for Barker Canyon fire simulation. Red contours represent the observed final fire perimeters; yellow shading represents the WRF-Sfire simulated final perimeters. The Barker Canyon fire started approximately on 2012-09-13 00:45 PDT. 
using initial WRF-simulated air temperature and relative humidity fields. The initial 10h, 100h and $1000 \mathrm{~h}$ fuel moistures were set to $4 \%, 8 \%$, and $7 \%$, respectively, based on the national fuel moisture maps. The simulation was run with the fuel moisture model (Mandel et al., 2014) to account for the significant fuel moisture changes observed for the Barker Canyon fire.

\begin{tabular}{|l|l|l|l|l|l|l|l|}
\hline $\begin{array}{l}\text { Domain } \\
\text { Number }\end{array}$ & $\begin{array}{l}\text { Number of } \\
\text { grid points } \\
\text { (x y z) }\end{array}$ & $\begin{array}{l}\text { Atmospheric } \\
\text { model reso- } \\
\text { lution }\end{array}$ & $\begin{array}{l}\text { Fire } \\
\text { model } \\
\text { resolution }\end{array}$ & $\begin{array}{l}\text { Time } \\
\text { step }\end{array}$ & $\begin{array}{l}\text { Surface } \\
\text { Model }\end{array}$ & PBL scheme & $\begin{array}{l}\text { Cumulus } \\
\text { scheme }\end{array}$ \\
\hline D01 & $151 \times 127 \times 37$ & $36 \mathrm{~km}$ & - & $180 \mathrm{~s}$ & Noah & $\begin{array}{l}\text { Mellor- } \\
\text { Yamada-Janjic }\end{array}$ & $\begin{array}{l}\text { Kain- } \\
\text { Fritsch }\end{array}$ \\
\hline D02 & $182 \times 142 \times 37$ & $12 \mathrm{~km}$ & - & $90 \mathrm{~s}$ & Noah & $\begin{array}{l}\text { Mellor- } \\
\text { Yamada-Janjic }\end{array}$ & $\begin{array}{l}\text { Kain- } \\
\text { Fritsch }\end{array}$ \\
\hline D03 & $406 \times 283 \times 37$ & $4 \mathrm{~km}$ & - & $30 \mathrm{~s}$ & Noah & $\begin{array}{l}\text { Mellor- } \\
\text { Yamada-Janjic }\end{array}$ & $\begin{array}{l}\text { Kain- } \\
\text { Fritsch }\end{array}$ \\
\hline D04 & $712 \times 364 \times 37$ & $1.33 \mathrm{~km}$ & - & $10 \mathrm{~s}$ & Noah & $\begin{array}{l}\text { Mellor- } \\
\text { Yamada-Janjic }\end{array}$ & - \\
\hline D05 & $196 \times 193 \times 37$ & $444 \mathrm{~m}$ & $22.2 \mathrm{~m}$ & $3.3 \mathrm{~s}$ & Noah & $\begin{array}{l}\text { Mellor- } \\
\text { Yamada-Janjic }\end{array}$ & - \\
\hline
\end{tabular}

The southern branch of the fire started from the ignition point reported by the Incident Information System (http://inciweb.nwcg.gov). The northern branch was ignited using locations of four lightning strikes observed within the fire perimeter on the day of ignition. The approximate locations of the fire ignition points are presented in Fig. 11. The Barker Canyon fire simulation was started on 09.09.2013 at 00 UTC (09.08.2012 17:00 PDT) and then run for 96h without observational nudging. The $96 \mathrm{~h}$ simulation took $12 \mathrm{~h} 52 \mathrm{~min}$ on $640 \mathrm{CPUs}$, with the first $24 \mathrm{~h}$ forecast ready in $3 \mathrm{~h}$ $13 \mathrm{~min}$.

\subsection{Barker Canyon fire with smoke as a passive tracer}

In this case, instead of using the full chemical smoke representation, a passive tracer was used to visualize smoke rise and dispersion. The modelled plume was estimated applying a threshold tracer concentration of 0.5. The highest model level of a tracer concentration above this threshold was used to compute the WRF-Sfire with passive tracers modelled plume-top height. One MISR overpass (067722-B52, date 2012-09-10) captured the Barker Canyon fire plume. The MISR retrieval indicated a maximum plume-top height of $3896 \mathrm{~m}$ ASL (Above Mean Sea Level), a median plume height of $2008 \mathrm{~m} \mathrm{ASL}$, and a plume-top height standard deviation of $852 \mathrm{~m}$, for a smoke plume spreading over terrain heights between approximately 400 to $1000 \mathrm{~m}$ ASL. Both model and MISR retrieval revealed that the plume-top heights fluctuated significantly as the smoke-plume emissions advected downwind of the fire. Therefore, for a better comparison between the simulated and MISR observed plume heights, both at their distance from the fire source are presented in Fig. 12. Scatter in the MISR plume-top heights is due to multiple data points at the same distance from the fire origin. The MISR data suggest that the Barker Canyon fire plume reached its maximum height of $3900 \mathrm{~m}$ ASL at $25 \mathrm{~km}$ downwind from its origin, while the WRF-Sfire plume reached its maximum height of $3500 \mathrm{~m}$ ASL approximately $50 \mathrm{~km}$ from its origin. 


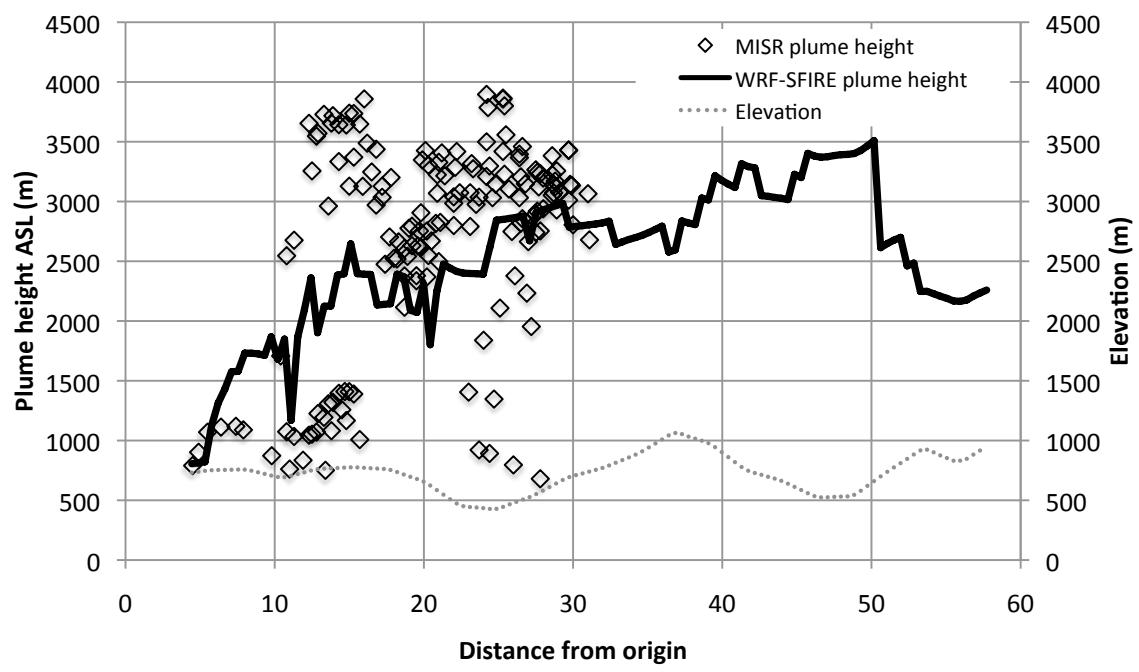

Figure 12: Downwind plume height observed by MISR (open diamonds) and simulated by WRFSfire (solid line). Observed plume heights are based on MISR retrieval O67722-B52 on 2012-09-10 19:12 UTC, and simulated plume heights from model output on 2012-09-10 19:15 UTC. Note elevation is given in m ASL (Above Sea Level).

From the standpoint of the air quality systems operating on grids of tens of kilometers, the differences between these two plume-top heights and their distances from the fire source are relatively small. There are multiple reasons for differences, but the primary reason for the difference in plume-top heights may be that the coarse resolution of the WRF atmospheric grid did not represent adequately the impact of strong fire-induced heating (confined to the narrow fireline) on fire convection. Dilution of fire-induced heat in WRF's surface layer, where plume width is smallest, may be responsible for the lower than observed plume rise. It is possible that the near-surface WRF grid cell size did not resolve adequately the buoyancy and pressure gradient forces associated with plume rise. Despite this, the WRF-Sfire modelled maximum plume height based on an inert tracer field matches the MISR observed heights well, with an underestimation of less than $10 \%$.

\section{Summary and conclusions}

This study couples WRF-Sfire with WRF-Chem to form WRFSC. As a coupled fire-atmosphere forecast system, WRF-Sfire makes it possible to resolve fire spread, heat release during flaming combustion, fire convection, fire emissions, and plume rise. As a coupled atmosphere-chemistry forecast system, WRF-Chem makes it possible to model the chemical processes associated with smoke or pollutants emitted by wildfires, downwind dispersion, deposition and associated chemistry. As a combination of WRF-Sfire and WRF-Chem, WRFSC makes possible, at every WRF time step, a completely integrated forecast of wildfire spread, pyro-plume rise, fire emissions, and short- and long- range transport, dispersion, and chemistry of wildfire-caused pollution. WRF-Sfire replaces WRF-Chem's reliance on a plume-rise module, assumptions about the size and heat release of the 
fire.

WRFSC was evaluated based on comparisons between available observations and the results of two wildfire simulations, a 48h WRFSC simulation of the 2007 Witch-Guejito Santa Ana fires and a 96h WRF-Sfire simulation with passive tracers of the 2012 Barker Canyon fire.

Particular matter PM2.5 concentrations were used to visualize smoke emissions from the WitchGuejito fires. PM2.5 dispersion indicates the ability of WRFSC to capture observed complex fire progression and smoke-plume behaviour. A comparison of PM2.5 concentrations to a corresponding MODIS satellite image suggested that WRFSC was able to simulate long-range smoke-plume dispersion associated with the growing fire perimeter for the Witch-Guejito fires.

Primary pollutants PM2.5 and NO observed by air quality stations within the fire domain were used to evaluate modelled concentrations. Although simulated results underestimated station observations, especially for NO, the differences between observed and WRFSC-forecasted PM2.5 and NO concentrations were not unacceptable compared to the large uncertainties in standard WRF-Chem forecasts influenced by wildfire (Pfister et al., 2011).

A stringent test of WRFSC's capabilities is an ozone forecast. WRFSC again underestimated station observations of ozone concentrations in terms of magnitude and changes with time. A secondary pollutant such as ozone is difficult to forecast, and several reasons are offered in Section 3.4 to explain the discrepancies between model results and observations. However, as discussed by Jaffe and Wigder (2012, and references therein), fire-related ozone concentrations are generally very difficult to predict due to the high sensitivity to the retaliative concentrations of its precursors (NOx and NMOC), importance of the mixing due to the downwind meteorology, interactions between radiation and photochemistry, as well as the impact of both the meteorological conditions and fuel characteristics on the combustion effciency.

One of the most important aspects of simulating wildfire plume transport is determining plume-top heights at which fire emissions are injected into the atmosphere. PM2.5 concentration results used to visualize smoke emissions from the Witch-Guejito fire were used to also calculate plume-top heights and vertical profiles of smoke emissions. The range of Witch-Guejito plume-top heights estimated from PM2.5 matched the MISR plume retrieval data for two other fires burning at approximately the same time and in the vicinity of the Witch-Guejito fires.

Based on available computing resources, the 48h WRFSC Witch-Guejito simulation with MOZART chemistry took approximately 30h and the 96h WRF-Sfire Barker Canyon simulation took approximately 13h. The WRFSC Witch-Guejito simulation was considerably more expensive computationally than the Barker Canyon fire simulation using inert scalar tracers to represent smoke. Both simulations ran faster than real time, with the Barker Canyon model set-up showing the promise of operational application. Barker Canyon plume-top heights based on the simple passive tracer smoke representation underestimated MISR observed plume-top heights by less than 10\%. These results suggest that, in addition to the size and heat release of the fire perimeter and its impact on plume-rise as it propagates, WRF-Sfire can provide, at reasonable computational cost, based on passive smoke tracers, the emissions profile needed by external chemical models. In present pollution forecasting operations, an external chemical model, such as CMAQ (Community Multiscale Air Quality modeling system), could then be used to compute smoke chemistry and larger-scale transport. 
There are many reasons for discrepancies between observations and model data, and it is outside the scope of this paper to determine exactly what they are. Certainly many result immediately from the simplified WRF-Sfire and WRF-Chem setup designed as a first test of WRFSC.

To isolate the impact of the simulated fire emissions on air quality, the simulations did not use the chemical boundary conditions and standard idealized chemical profiles provided by WRF-Chem for atmospheric-chemistry initialization. All anthropogenic and biogenic emissions were omitted. Fuel moisture was kept constant throughout the Witch-Guejito simulation. Both fire simulations were done without updating the model state with current meteorological observations during the run. Untested, emission fluxes were computed simply as the products of the fuel-combustion rates and fuel-specific emission factors. Sfire model does not distinguish between flaming and smoldering. The effect of slower burning fuels on the emissions is that they emit smoke longer. This simplified treatment of the link between the fuel consumption and fire emissions may not be adequate for fires with significant emissions during the smoldering stage. It is not known if three MODIS Land Cover Types are enough to represent the chemical emissions from wildfires spreading across thirteen possible fuel-bed categories, and WRF-Chem's global emission factors for certain fuel types may differ from actual emission factors for those fuel types in certain geographic regions. It is possible that the simulation period was too short for the chemical model to spin up. Simulated plume rise is sensitive to the atmospheric model cell size. When a horizontal grid as large as $500 \mathrm{~m}$ is used in the fire domain, the size of the near-surface grid volume may dilute the strength of fire heating input into the surface level of atmospheric model WRF enough to under-represent temperature and buoyancy forces in the plume. Simulated plume-rise may be underestimated. It is not known what horizontal grid resolution is required to reach a model plume rise insensitive to grid-size.

Most of these issues summarized above can possibly be mitigated with access to greater and more efficient computing resources. This is only pilot study, using a very simple model setup, designed to demonstrate the potential of WRF-Sfire and WRF-Chem as an integrated system for use by natural resource managers. What the study does establish is the increased level of detail provided by the system, such as locations of high reaction intensity, smoke emissions, and plume injection heights that can provide a more comprehensive understanding of the wildfire environment, wildfire behaviour, and downwind ramifications of wildland fire emissions on air quality.

Future quantitative research is warranted to prove the validity WRFSC, and evaluation of the model by comparison to new and different data sets is necessary. Observations that provide information for all components of the system - local micrometeorology, fire spread, fire emissions, plume rise, and dispersion and chemistry - are needed. Coordinated field measurements of firespread data, fire-heat release, and in-situ meteorological conditions are required to evaluate the fire spread component of the system. Radiosonde data are needed to provide information on the vertical structure of wind, moisture and temperature. Airborne measurements in the smoke plume of the updraft velocities, temperature, and chemical composition, combined with estimates of local emission factors, are needed to analyze fire-plume dynamics, dispersion, and chemistry. A comprehensive dataset providing information on all these aspects is essential to fully understand how the integrated system performs and what components need to be improved. FireFlux (Clements et al., 2007) and RxCADRE (Ottmar, 2013) experiments provide the most comprehensive datasets available for model evaluation purposes. Unfortunately, the former provides meteorological insight without airborne smoke data, while the latter (fire L2f) is a great source of the smoke and fire data but without in-plume meteorological measurements of the updraft velocities and temperature. 
Future field experiments are needed to provide comprehensive data sets for extensive evaluation and validation of WRF-Sfire, WRF-Chem, and WRFSC.

ACKNOWLEDGMENTS. This research was partially supported by the National Science Foundation (NSF) grants AGS-0835579 and DMS-1216481, and National Aeronautics and Space Administration (NASA) grants NNX12AQ85G and NNX13AH9G. This work partially utilized the Janus supercomputer, supported by the NSF grant CNS-0821794, the University of Colorado Boulder, University of Colorado Denver, and National Center for Atmospheric Research. 


\section{Bibliography}

Albini, F., 1994: PROGRAM BURNUP: a simulation model of the burning of large woody natural fuels. Technical Report Research Grant INT-92754-GR, USDA Forest Service, Missoula Fire Science Laboratory, Missoula, MT.

Anderson, H., 1982: Aids to determining fuel models for estimating fire behavior. Technical Report INT-122, USDA Forest Service, Intermountain Forest and Range Experiment Station, Ogden, UT, USA, 22 pp.

Bytnerowicz, A., S. Schilling, D. Alexander, W. Fraczek, and M. Hansen, 2010: Passive monitoring to estimate $\mathrm{N}$ (NO2, HNO3, NH3) exposure in remote areas and geospatial analysis to optimize monitoring networks in the Athabasca Oil Sands Region. 103 Annual Conference and Exhibition of the Air $\&$ Waste Management Association, Calgary Canada. Extended Abstract 2010-A-563AWMA.

Clark, T., M. Jenkins, J. Coen, and D. Packham, 1996: A coupled atmosphere-fire model: Role of the convective froude number and dynamic fingering at the fireline. International J. Wildland Fire, 6, 177-190.

Clements, C., S. Zhong, S. Goodrick, J. Li, X. Bian, B. Potter, W. Heilman, J. Charney, R. Perna, M. Jang, D. Lee, M. Patel, S. Street, and G. Aumann, 2007: Observing the dynamics of wildland grass fires: FireFlux - a field validation experiment. Bull. American Meteor. Soc., 88, 1369-1382, doi:10.1175\/BAMS-88-9-1369.

Coen, J., M. Cameron, J. Michalakes, E. Patton, P. Riggan, and K. Yedinak, 2012: WRF-Fire: Coupled weather-wildland fire modeling with the Weather Research and Forecasting model. J. Appl. Meteor., 52, 16-38, \doi:10.1175/JAMC-D-12-023.1.

Eidsmoe, G., 2007: Investigation report: Guejito fire. Technical Report CA-MVU-010484, California Department of Forestry and Fire Protection.

Emmanuel, S., 2000: Impact to lung health of haze from forest fires: The Singapore experience. Respirology, 5, 75-182, doi:10.1046/j.1440-1843.2000.00247.x.

Emmons, L., S. Walters, P. Hess, J. Lamarque, G. Pfister, D. Fillmore, C. Granier, A. Guenther, D. Kinnison, T. Laepple, J. Orlando, X. Tie, G. Tyndall, C. Wiedinmeyer, S. Baughcum, and S. Kloster, 2010: Description and evaluation of the model for ozone and related chemical tracers, version 4 (MOZART-4). Geoscientific Model Development, 3, 43-67, $\backslash$ doi:10.5194/gmd-3-43-2010.

Freitas, S., K. Longo, R. Chatfield, D. Latham, M. Silva Dias, M. Andreae, E. Prins, J. Santos, R. Gielow, and J. Carvalho, 2007: Including the sub-grid scale plume rise of vegetation fires in low resolution atmospheric transport models. Atmospheric Chemistry and Phys., 7, 3385-3398.

Freitas, S., K. Longo, J. Trentmann, and D. Latham, 2010: Technical note: Sensitivity of 1-D smoke plume rise models to the inclusion of environmental wind drag. Atmospheric Chemistry and Phys., 10(2), 585-594, doi:10.5194\/acp-10-585-2010. 
Goodrick, S., G. Achtemeier, N. Larkin, Y. Liu, and T. Strand, 2012: Modelling smoke transport from wildland fires: a review. International J. Wildland Fire, 22(1), 83-94, http://dx.doi. org/10.1071/WF11116.

Grell, G., S. Peckham, R. Schmitz, S. McKeen, G. Frost, W. Skamarock, and B. Eder, 2005: Fully coupled "online" chemistry within the WRF model. Atmospheric Environment, 39, 6957-6975, \doi:10.1016/j.atmosenv.2005.04.027.

Hardy, C., R. Ottmar, J. Peterson, J. Core, and S. P., 2001: Smoke management guide for prescribed and wildland fire. Technical report, National Wildfire Coordination Group. http: //www.nwcg.gov/pms/pubs/SMG/SMG-72.pdf.

Jaffe, D., and N. Wigder, 2012: Ozone production from wildfires: A critical review. Atmospheric Environment, 51, 1-10, http://dx.doi.org/10.1016/j.atmosenv.2011.11.063.

Kochanski, A., M. Jenkins, S. Krueger, J. Mandel, and J. Beezley, 2013: Real time simulation of 2007 Santa Ana fires. Forest Ecology and Management, 15, 136-149, \doi:10.1016/j.foreco. 2012.12 .014 .

Larkin, N., S. O’Neill, R. Solomon, S. Raffuse, T. Strand, D. Sullivan, C. Krull, M. Rorig, J. Peterson, and S. Ferguson, 2009: The BlueSky Smoke Modeling Framework. International J. Wildland Fire, 18, 906920, \doi:10.1071/WF07086.

Lavdas, L., 1996: Program VSMOKE users manual. Technical Report SRS-6 (Macon: GA), USDA Forest Service, Southeastern Forest Experiment Station General.

Mandel, J., 2012: Openwfm: Fire code in WRF release. Technical report, Open Wildland Fire Modeling e-Community. http://www.openwfm.org/wiki/Fire_code_in_WRF_release.

Mandel, J., 2013: Openwfm: Coupled WRF and SFIRE model user's guide. Technical report, Open Wildland Fire Modeling e-Community. http://www.openwfm.org/wiki/Users_guide.

Mandel, J., S. Amram, J. Beezley, G. Kelman, A. Kochanski, V. Kondratenko, B. Lynn, B. Regev, and M. Vejmelka, 2014: New features in WRF-SFIRE and the wildfire forecasting and danger system in Israel. Nat. Hazards Earth Syst. Sci. Discuss., 2, 1759-1797, doi:10.5194/nhessd-2-1759-2014.

Mandel, J., J. Beezley, and A. Kochanski, 2011: Coupled atmosphere-wildland fire modeling with wrf 3.3 and Sfire. Geoscientific Model Development, 4, 1-20, doi:10.5194/gmd-4-1-2011.

Mesinger, F., G. DiMego, E. Kalnay, K. Mitchell, P. Shafran, W. Ebisuzaki, D. Jović, J. Woollen, E. Rogers, E. Berbery, M. Ek, Y. Fan, R. Grumbine, W. Higgins, H. Li, J. Lin, G. Manikin, D. Parrosh, and W. Shi, 2006: North american regional reanalysis. Bull. American Meteor. Soc., 87, 343-360, doi:10.1175/BAMS-87-3-343.

Ottmar, R., 2013: Data set for fuels, fire behavior, smoke, and fire effects model development and evaluation the RxCADRE Project. Technical report, U.S. Forest Service, Pacific Northwest Research Station, Seattle, WA. http://www.firelab.org/ResearchProject_Files/RxCADRE_ 01_07_11_Final_Attachment-1.pdf.

Pfister, G., J. Avise, C. Wiedinmeyer, D. Edwards, L. Emmons, G. Diskin, J. Podolske, and 
A. Wisthaler, 2011: CO source contribution analysis for California during ARCTAS-CARB. Atmospheric Chemistry and Phys., 11, 7515-7532, doi:10.5194\/acp-11-7515-2011.

Rothermel, R., 1972: A mathematical model for predicting fire spread in wildland fuels. Technical Report Research Paper INT 115. (Ogden, UT), USDA Forest Service, Intermountain Forest and Range Experiment Station, 1-46.

Scire, J., 2000: CALPUFF: overview of capabilities. Technical Highlights of EPA's 7th Conference on Air Pollution Modeling. http://www.epa.gov/scram001/7thconf/information/t029day1. pdf.

Sestak, M., and A. Riebau, 1988: SASEM, simple approach smoke estimation model. Technical Report Note 382, US Bureau of Land Management.

Skamarock, W., J. Klemp, J. Dudhia, D. Gill, D. Barker, M. Duda, W. Wang, and J. Powers, 2008: A description of the Advanced Research WRF version 3. Technical Report NCAR Technical Note 475, National Center for Atmospheric Research. http://www.mmm.ucar.edu/wrf/users/ docs/arw_v3.pdf.

Trentmann, J., G. Luderer, T. Winterrath, M. Fromm, R. Servranckx, C. Textor, M. Herzog, H.-F. Graf, and M. Andreae, 2006: Modeling of biomass smoke injection into the lower stratosphere by a large forest fire (part I): Reference simulation. Atmospheric Chemistry and Phys., 6, 5247-5260, www . atmos-chem-phys . net/6/5247/2006.

Val Martin, M., R. Khan, J. Logan, R. Paugam, M. Wooster, and C. Inhoku, 2012: Space-based observational constraints for 1-d fire smoke plume-rise models. J. Geophys. Res., 117, D22204, doi:10.1029/2012JD018370.

Van Wagner, C., and T. Pickett, 1985: Equations and FORTRAN program for the Canadian Forest Fire Weather Index System. Technical Report 33, Canadian Forestry Service.

Wiedinmeyer, C., S. Akagi, R. Yokelson, L. Emmons, J. Al-Saadi, J. Orlando, and A. Soja, 2011: The Fire INventory from NCAR (FINN): a high resolution global model to estimate the emissions from open burning. Technical report, National Center for Atmospheric Research. Idoi : 10.5194/ gmd-4-625-2011. 